


\section{$4=14=$}

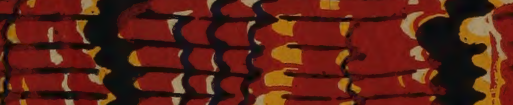

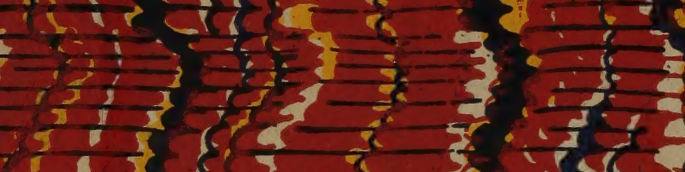

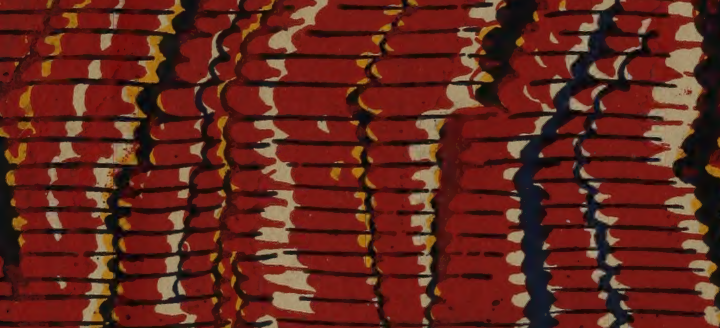

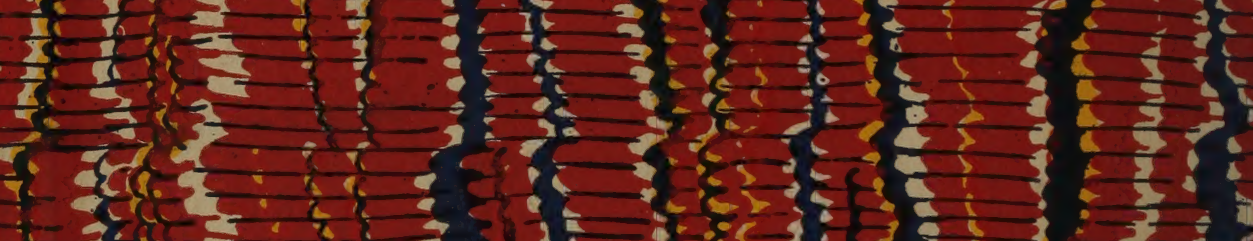

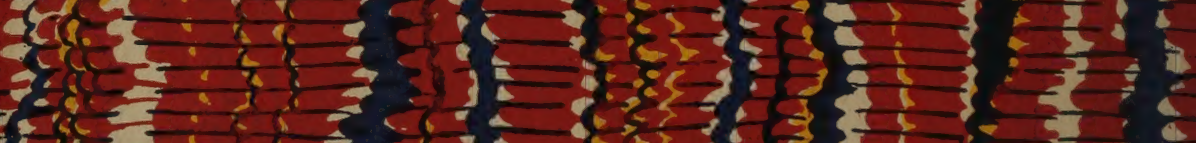

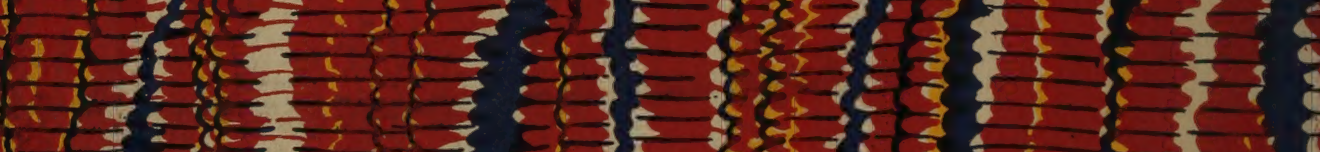

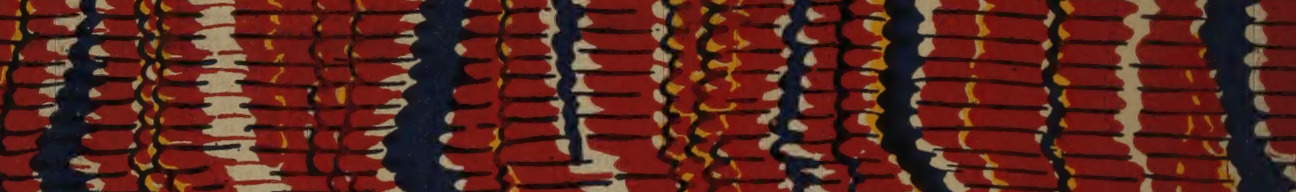

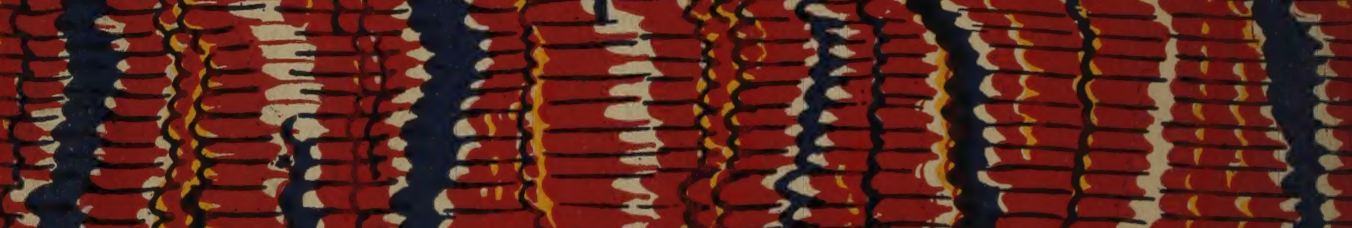

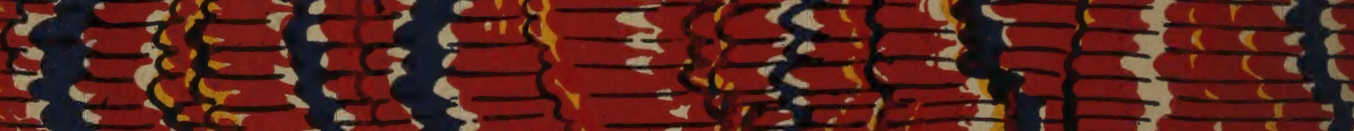

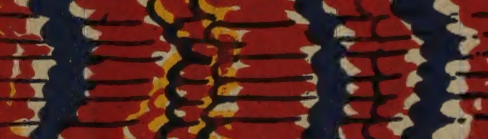
$-1, \div 2=$

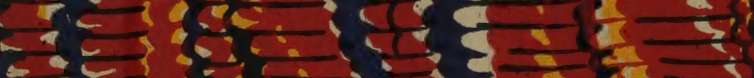

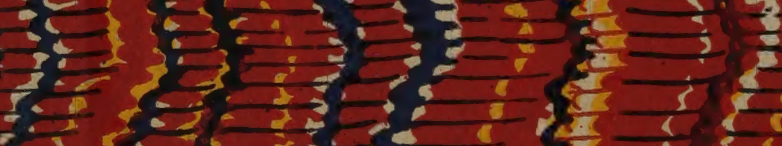

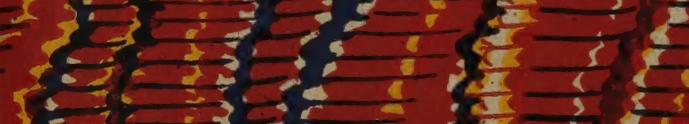

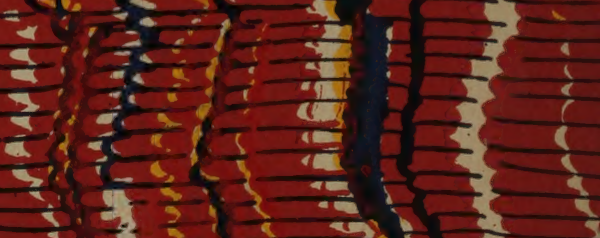

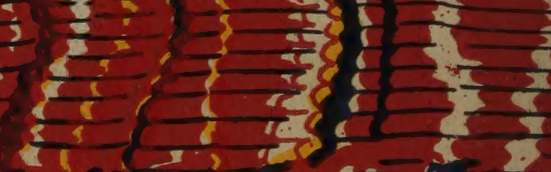

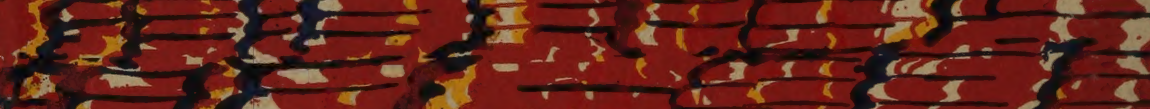

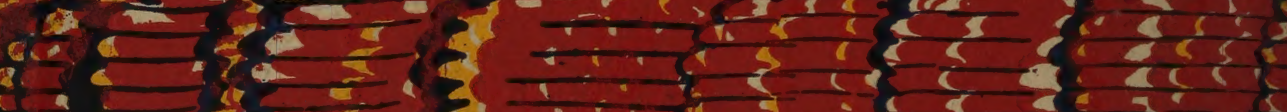

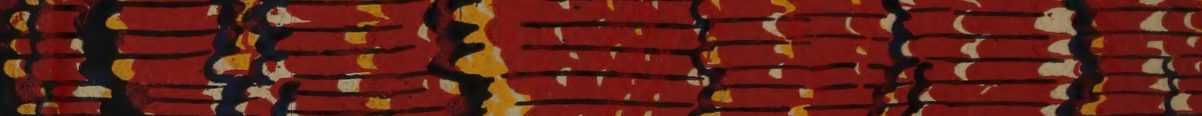

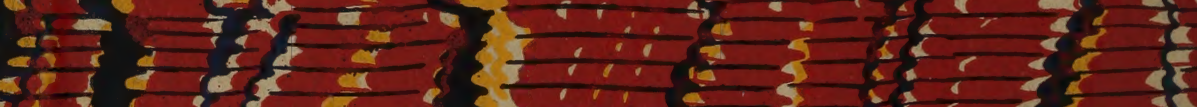

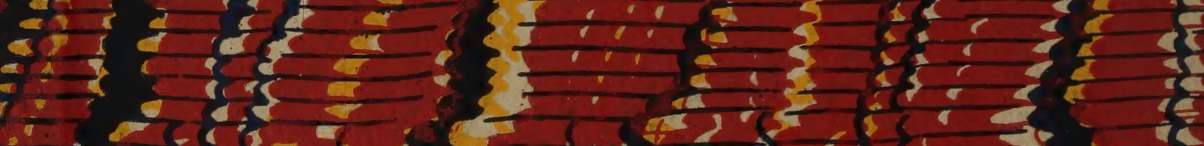

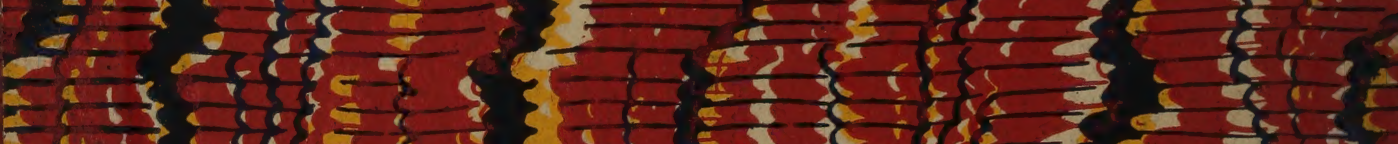
if

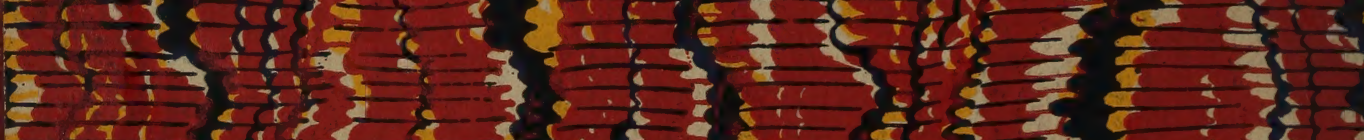
को 1 की

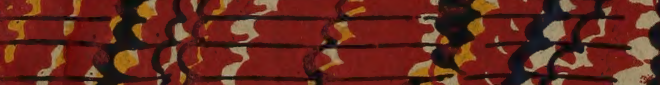
$\frac{1}{1:}$ है:

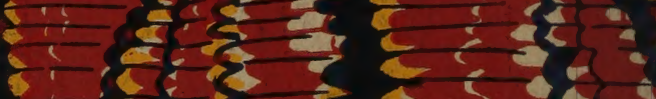

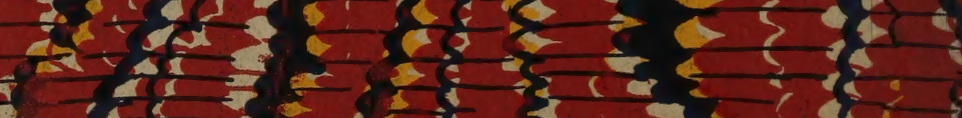
$=x \rightarrow-12$ 


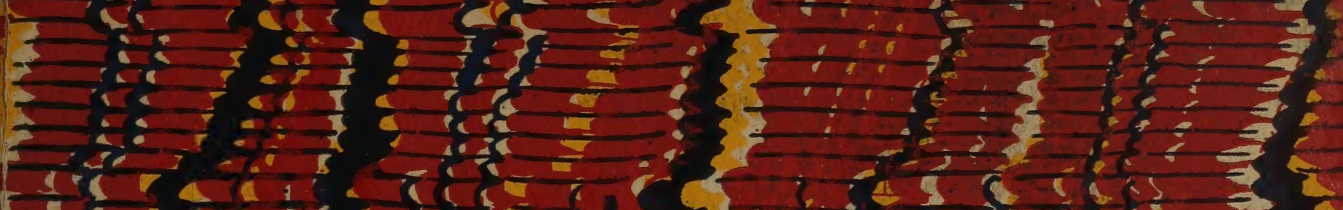

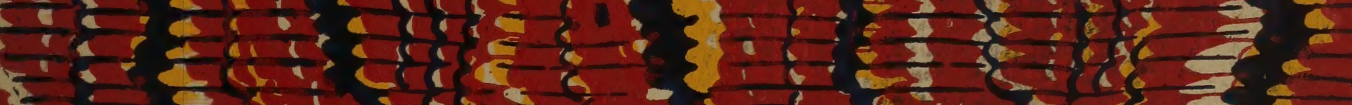

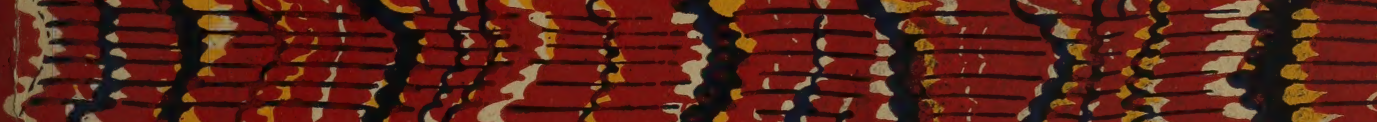

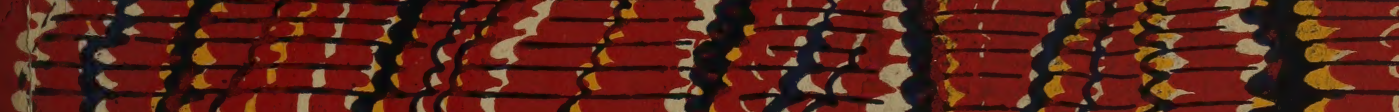

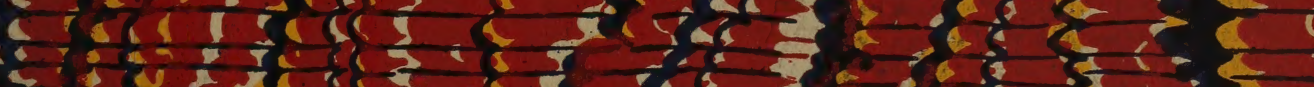

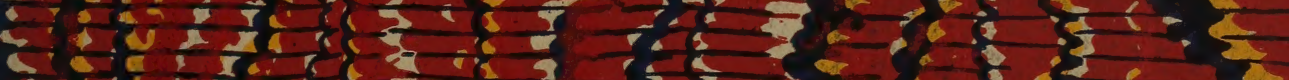

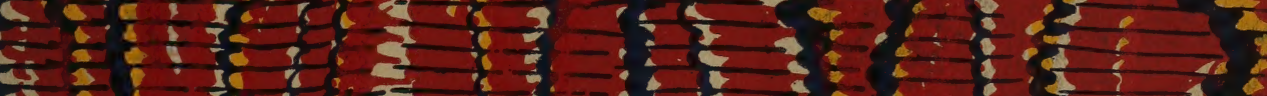

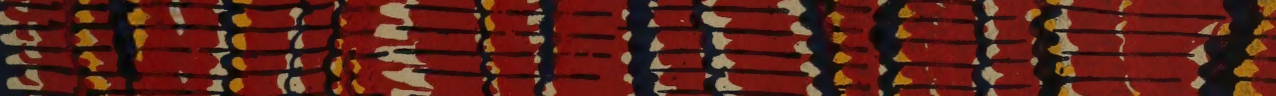

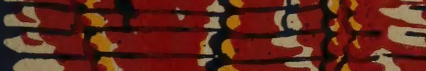

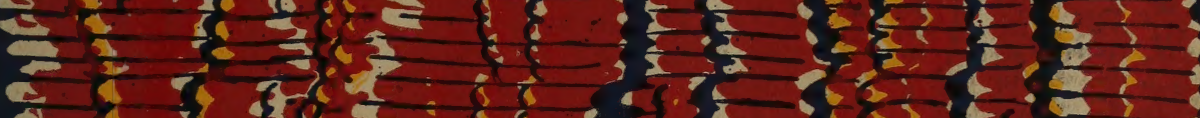

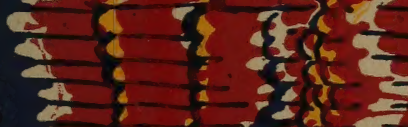

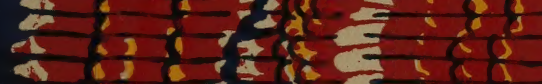

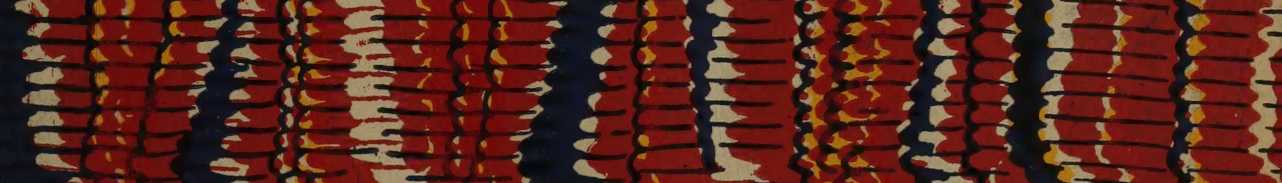

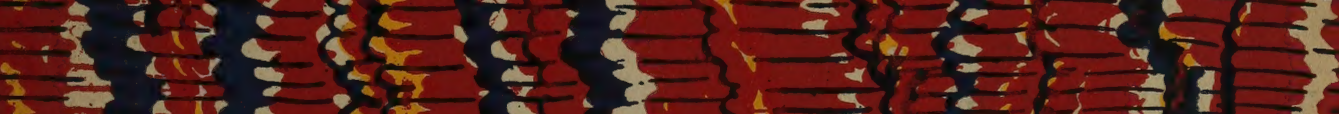

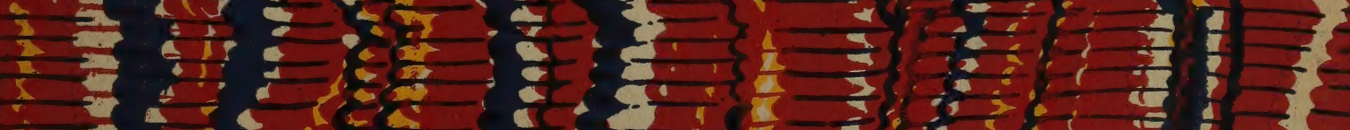
5

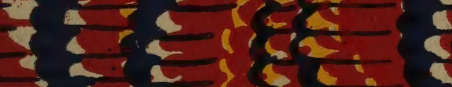

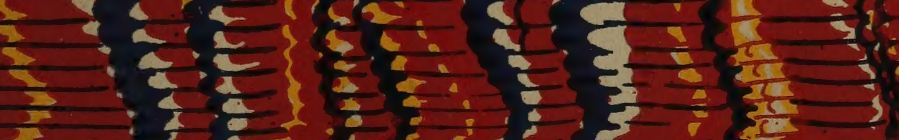

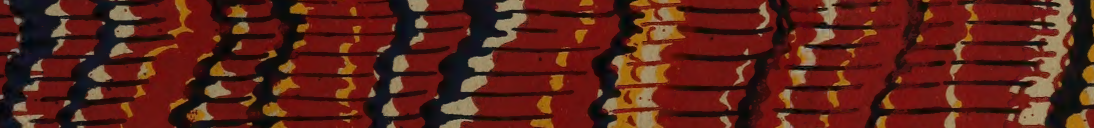

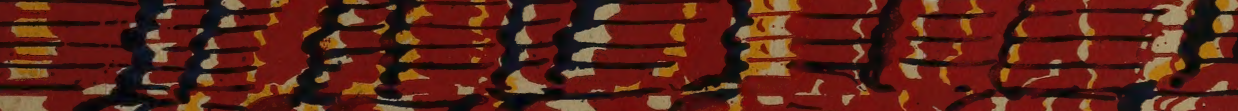

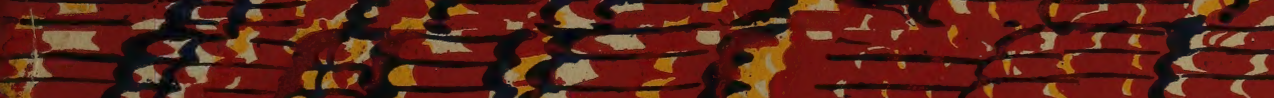

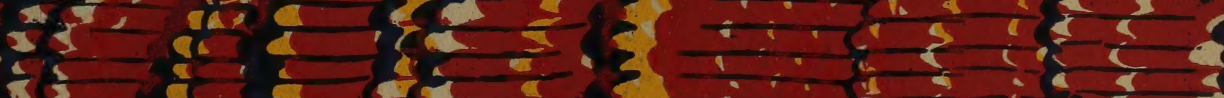

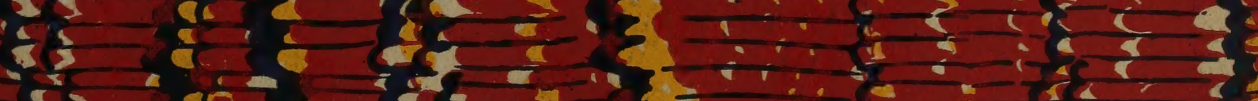

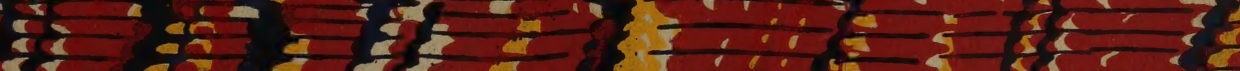

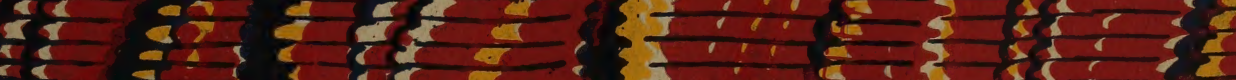

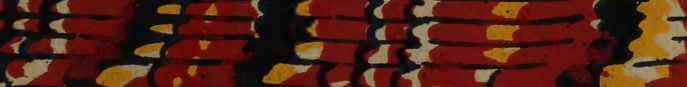

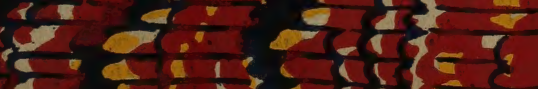
e 1

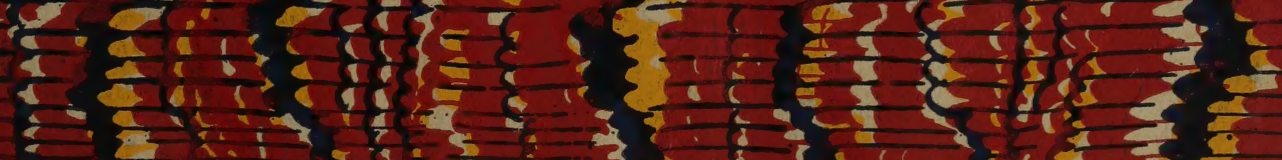

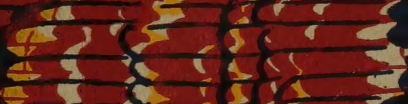

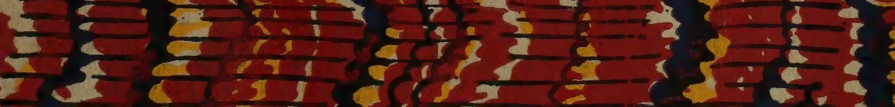

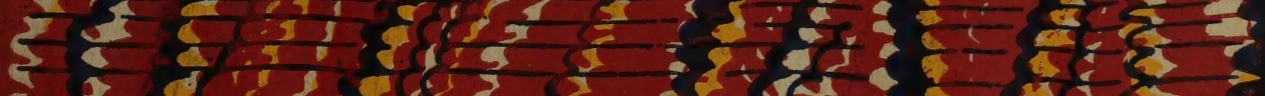

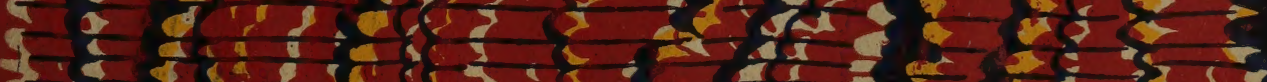
3 

2

- 



\section{CARDED 1928}

1. IV.--Notes on Some Rare and Interesting Marine Crustacea. 22nd Ann. Rpt. Fish. Bd. Scotland, Pt. 3, 1904, pp. 242261, pls. XIII-XV.

2. VII.--On Some Parasites of Fi shes new to the Scottish Marine Fauna.

22nd Ann. Rpt. Fish. Bd. Scotland, Pt. 3, 1904, pp. 275$280, \mathrm{pl}$. XVII.

3. III.--Observations on some parasites of fishes new or rare in Scottish waters.

23d Ann. Rpt. Fish. Bd. Scotland, 1905, pp. 108-119, pls. $\nabla, V I$.

4. VI.--On some new and rare Crustacea from the Scottish Seas. 23d Ann. Rpt. Fish. Bd. Scotland, 1904, pt. 3, (1905), pp. 14l-153, pls. X-XIII.

5. II.--Observations on the Otoliths of some Teleostean Fishes, 24th Ann. Rpt. Fish. Bd. Scotland, Pt. 3, 1905 (1906), pp. 48-82, pls. I-V.

6. IX.--Notes on new and rare Copepoda fram the Scottish Seas.

24th Ann. Rpt. Fish. Bd. Scotland, Pt. 3, 1905 (1906), pp. 275-280, pl. XIV.

7. III.--Some Additional Notes on Copepoda from the Scottish Seas.

25th Ann. Rpt. Fish. Bd. Scotland, 1906 (1908), pp. 209220, pls. XIII-XV.

8. VI.--Some Obserrations on the Food of the Herring. 25th Ann. Rpt. Fish. Bd. Scotland, 1906 (1908), Pt. 3, pp. 260-271.

9. III.--Some Notes on Fish Parasites. 26th Ann. Rpt. Fish. Bd. Scotland, Pt. 3, 1909, pp. 7392, pls. III-VII.

10. III.--Notes on the Distribution of Pelagic Crustacea in Lower and Upper Loch Fyno.

27th Ann. Rpt. Fish. Bd. Scotland, 1910, pp. 74-99.

11. IV.--On the Food of the Halibut, with notes on the food of Scorpaena, Phycis Blennoldes, the Garpike and Dhimaera Monstrosa.

28th Ann. Rpt. Fish. Bd. Scotland, 1911, pp. 24-37.

12. VII.--Notes on some Teemotode Parasites of Fishes. 28 th Ann. Rpt. Fish. Bd. Scotland, 1911, pp. 68-71, pls. VII-VIII. 



\section{$\frac{95632}{5 m i d 4}$}

AMINUAL REPORT

OF THE

FISHIRY BOARD.

SCOTLAND.

$1904-1912$

VOL. 3.

T.SCOTT. 


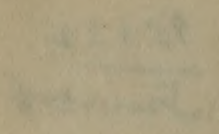

$x^{3} 3$

1.

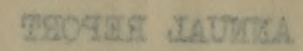

팔ำ 50

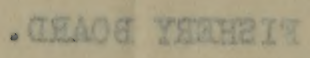

- Orhastopa

sirer - AOEI

. Oni , Amoarzuso

$.8 . .107$

.72008 .2 


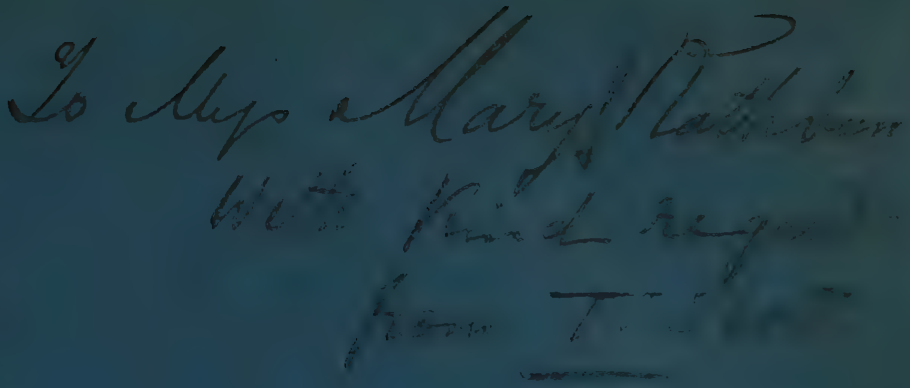

IV.-NOTES ON SOME RARE AND INTERENTING MAPINE ('RUSTACEA.

BY THOMAS SCOTH', LL.D., F.C.S.

(Plates XIII.-XV.)

[Reprinted firom Tirentw-second Annual Report of the Fishery Boctorl. for Sontlond, Part III., publisher. August 29. 1904.7

$$
276743
$$



[Reprinted from Tuenty-second Annual Report of the Fishery Bourd for Scotland, Part III., published August 29, 1904.]

\title{
IV.-NOTES ON SOME RARE AND INTERESTING MARINE CRUSTACEA.
}

\author{
Bу Thомаs Scotт, LL.D., F.L.S.
}

\author{
(Plates XIII.-XV)
}

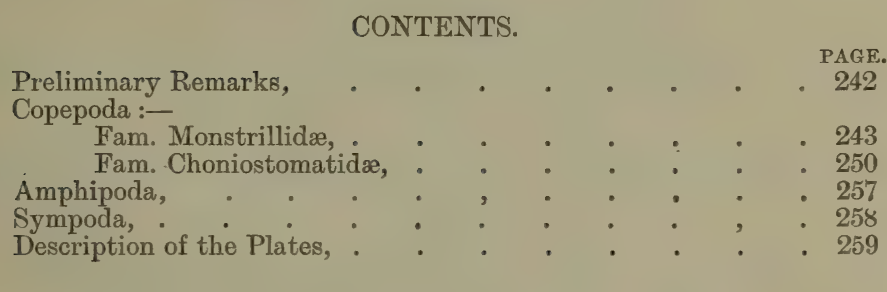

\section{Preliminary Remarks.}

In the foilowing notes I have described a number of minute Crustaceans belonging to the Monstrillidæe and the Choniostomatidæ-two families of Copepoda containing aberrant and parasitic forms of more than usual interest. A few forms belonging to other groups more or less rare in the Scottish seas are also recorded here.

The species recorded here belonging to the Monstrillidæ are as follows:-

$$
\begin{gathered}
\text { Monstrilla grandis, Giesbrecht. } \\
\quad \text { longicornis, I. C. Thompson. } \\
\quad \text { gracilicauda, Giesbrecht. } \\
\quad \text { anglica, Lubbock. } \\
\quad \quad \text { dubic, T. Scott, sp. n. }
\end{gathered}
$$

Thaumaleus thompsoni, Giesbrecht.

" rigidus (I. C. Thompson).
" $\quad$ retlandicus, T. Scott, sp. n.
rostratus, T. Scott, sp. n.

The following are the names of the seven species belonging to the Choniostomatidæ which are also described :-

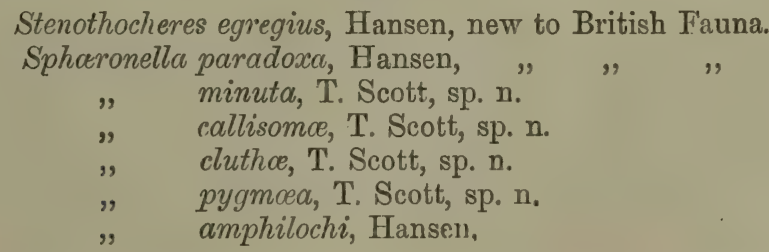

A description is furnished of each of the species mentioned above, and this is illustrated by drawings which have been prepared by my son, Mr. A. Scott, A.L.S., who also prepared most of the dissections required. The prepariug of these dissections was in some cases rendered more difficult when the species happened to be represented by only a single 
specimen whose appendages were not very obvious even with a moderately high magnification.

Some moderately rare species of Amphipoda and Sympoda are recorded at the end of the paper, the names of which are as follows:-

\author{
Hyperia medusarum (O. F. Muller). \\ Tryphana malmi, Boeck. \\ Anonyx nugax (Phipps). \\ Hoplonyx cicada (Fabr.). \\ Harpinia pectinata, G. O. Sars. \\ Metopa borealis, G. O. Sars. \\ Paratylus falcatus (Metzger). \\ Megaluropus agilis, Norman \\ Idothea neglecta, G. O. Sars. \\ Eudorellopsis deformis, Kryöer. \\ Pseudocuma similis, G. O. Sars.
}

The following are the descriptions of the various species referred to :-

\title{
COPEPODA.
}

\section{Fam. Monstrillide}

Genus Monstrilla, Dana, 1848.

Monstrilla grandis, Giesbrecht. Pl. xiii., fig. 11, 12 ; pl. xiv., fig. 9-11; pl. $x \mathrm{v}$., fig. 1, 2.

1892. Monstrilla grandis, Giesb., Pelag. Copep. des Golfes v. Neapel, p. 588, pl. 46, fig. 2, 8, 11, 17, 19, 24, 25, 35, 39 .

Description of the Female:-In this species the antennules of the female, which are moderately stout, are scarcely equal to one-fourth the length of the animal; their structure is somewhat similar to that of the antennules of $M$. graciticauda, but the articulations are rather more distinct (fig. 9, pl. xiv.).

The fifth pair of thoracic feet are sub-cylindrical, about twice as long as broad, and with a somewhat bi-lobed extremity (fig. 10, pl. xiv.); the exterior lobe bears three setæ, the inner one is small but the other two are elongated. The inner lobe appears to be furnished with only a single apical seta, but our dissection shows what appears to be the base of a seta on the inner margin of this lobe, the seta itself having probably been broken off; the position of this seta is indicated on the drawing by dotted lines.

The abdomen consists of three segments, but the first, which is larger than the next two combined, is divided into two portions by a pseudoarticulation as shown by the drawing (fig. 11, pl. xiii., and fig. 11, pl. xiv.); the second and third segments are sub-equal and are together much smaller than the first segment.

The furcal joints are each provided with six setæ, one being situated on the outer edge near the base of the joint while the others spring from the apex (fig. 11, pl. xiv.); one of the apical setæ near the inner edge is very small.

The female represented by the drawing (fig. 11, pl. xiii.) measures $4.25 \mathrm{~mm}$. (about $\frac{1}{6}$ of an inch).

Description of the Male:-The male is much smaller than the female; the specimen represented by the drawing (fig. 12, pl. xiii.) measures only $2 \mathrm{~mm} .\left(\frac{2}{25}\right.$ of an inch). 
The antennules of the male, which are proportionally rather longer than those of the female, are five-jointed, the last joint being hinged to the preceding one (fig. 1, pl. xv.).

The first and second segments of the male abdomen are not coalescent as in the female, but otherwise the two sexes are nearly alike.

The armature of the furcal joints (fig. 2, pl. xv.) is similar to that of the female.

The fifth pair of feet resemble very closely the fifth pair of the male of M. longiremis.

Habitat.-Head of Loch Fyne (Firth of Clyde), November 28, 1899, one female, and January 30, 1901, a male and a female.

Professor G. S. Brady records a Monstrilla, obtained at Cullercoats in July, 1900, which he thinks may be the male of $M$. grandis, Giesbrecht,* and I. C. Thompson mentions the occurrence of the same species in the vicinity of the Channel Islands. $\uparrow$

Monstrilla longicornis, I. C. Thompson. Pl. xiii., fig. 1-7.

1890. Monstrilla longicornis, I. C. Thompson, Trans. L'pool. Biol. Soc., vol. iv., p. 119, pl. iv., figs. 1, 2, and 4 ( $\left.\varsigma^{\top}\right)$.

1892. Monstrilla longiremis, Giesb., Pelagischen Copepoden des Golfes von Neapel, p. 589, pl. 46, figs. 10, 14, 22, 37, and 41 (ㅇ).

1902. Monstrilla longiremis, T. Scott, 20th Rept. Fishery Board for Scotland, pt. iii., p. 469, pl. xxv., figs. 3 and 4 (ㅇ).

The antennules in both the female and male are elongated and slender, being in some examples nearly half as long as the cephalothorax and abdomen combined; but their length seems to vary to some extent in different individuals, and those of the male appear to be proportionally rather longer than in the female. The male antennules are composed of six joints, and the articulation between the fifth and sixth is so hinged that the sixth joint can be folded inwards ; the second and last joints are of nearly equal length and considerably longer than any of the others (fig. 6). In the female antennules all the joints except the first appear to be coalescent, so that each antennule is apparently only two-jointed (fig. 3).

The fifth thoracic feet of the female consist each of a sub-cylindrical plate, but the proximal half of the leg is rather wider than the lower half and is defined from it by a distinct notch on the inner margin, and from this notch there springs a moderately long seta; three other setro spring from the distal extremity of the leg, but the innermost one is short while the other two are elongated; all the setæ appear to be more or less plumose (fig. 4).

The fifth feet of the male are somewhat rudimentary, each being represented by a single moderately long plumose seta which springs from a small tubercle near the lower ventral margin of the last thoracic segment. The genital appendages are narrow and spiniform (fig. 7).

The furcal joints in the female are each furnished with five moderately long setæ, but there are only four setæ to each of the furcal joints in the male. This appears to be the only British species of Monstrilla in which the number of furcal setæ in the female is five.

The male of Monstrilla longicornis does not appear to have been previously recorded except by I. C. Thompson.

* Nat. Hist. T'rans. Northumb., Durham, and Newcastle, vol. xiv., p. 64, pl. iv., fig. 1-3.

†Journ. Marine Zool, and Microscopy, vol. ii., p. 97 (No. 8, December, 1897). 
The following are the localities whence $I$ have obtained this species and the dates when the different specimens were collected :-

Firth of Forth, between Fidra and the Bass Rock, October 18, 1890 (ㅇ).

Firth of Forth, east of Inchkeith, August 14, 1891 ( $\left.+\& \delta^{\top}\right)$.

Firth of Forth (locality not stated), 1893 (ㅇ \& o ).

Firth of Forth, Station V. (to the west of May Island), August 30, 1894 ( 9 \& $\left.\delta^{\top}\right)$.

Firth of Forth, Station V., July 24, 1901 (q).

Firth of Tay, at Buddon, December 5, 1902 ().

Thirty-five miles east of May Island (per s.s. "Glenogle," of Aberdeen), August 20, 1903 ( $q \& \sigma^{\top}$ ).

Off Aberdeen about ten miles, November 11, 1901 (q).

Firth of Clyde, off the Ayrshire coast, November (date not stated), 1895 ( 9 ).

Firth of Clyde, head of Loch Fyne, December 11, 1897 (ㅇ).

Firth of Clyde, Whitefarland Bay, Arran, July 6, 1899 (o').

Solway Firth, Luce Bay (per Andrew Scott), November 26, 1901 (q).

Larne Harbour, Ireland (per Andrew Scott), January 14, 1904.

The female represented by the drawing (fig. 1) measured $3.1 \mathrm{~mm}$, which is similar to the size given by Dr. Giesbrecht; the length of the male which the drawing represents (fig. 2) is $2 \mathrm{~mm}$.

One or two of the more obvious characters by which $\boldsymbol{M}_{i}$. longicornis may be distinguished from other forms are the long and somewhat slender antennules, the form and armature of the fifth pair of thoracic feet, and the number of the furcal setæ. The structure of the abdomen appears also to differ to some extent from the other species of Monstrilla recorded here.

It may be remarked further that the integument in this species when examined with the microscope and under a moderately high power is seen to have a granular appearance not observed in other species (see the drawings, figs.1 and 2 ).

That I. C. Thompson's Monstrilla longicornis is identical with $M$. longiremis, Giesbrecht, must, I think, be admitted. The long antennules, the granular appearance of the integument, the number of furcal setæ, and the structure of the abdomen show that it can be nothing else, and as 'Thompson's name was published two year's before that of Dr. Giesbrecht it must be restored. Thompson does not appear to have seen the female or Dr. Giesbrecht the male of this species.

Monstrilla gracilicauda, Giesbrecht. Pl. xiii., fig. 8-10; pl. xiv., fig. 15.

1892. Monstrilla gracilicauda, Giesb., op. cit., p. 587, pl. 46, figs. 9, 16, 18, 29, 32, 43.

In the female of Monstrilla gracilicauda the antennules are rather shorter than in the species just described. They appear to be fourjointed, the first three being small, while the end joint is equal to the entire length of the other three (fig. 8, pl. xiii.).

The fifth pair of thoracic feet (fig. 15, pl. xiv.) are sub-quadrate in outline, rather longer than broad, and somewhat gibbous at the distal end as shown in the drawing; each foot is furnished with three plumose setæ, one on the outer aspect and two at the apex, the feathering is very delicate and can only be seen by using a moderately high magnification.

The abdomen consists of four segments, the first segment, which 
appears to consist of two coalescent segments, is of a sub-cylindrical form but tapers slightly towards the distal extremity; it is about one-third longer than the breadth at the widest part and nearly twice the entire length of the next segments. The third segment is only about half the length of the second one.

The furcal joints are each provided with six setæ arranged as shown in the drawing (fig. 10, pl. xiii.), but one of the setæ is very small.

The length of the specimen represented by the drawing is $3.1 \mathrm{~mm}$., which is somewhat larger than that stated by Dr. Giesbrecht. No males of this species have been observed hitherto.

M. gracilicauda has been collected at the following places :-

Firth of Forth, above Queensferry, June 26, 1890 (q).

Firth of Forth, off Musselburgh, September 29, 1892 (q).

*35 miles east of May Island, Firth of Forth (per s.s. "Glenogle"), August 20, 1903 (q).

Firth of Clyde, Whitefarland Bay, Arran, July 6, 1899 ().

Firth of Clyde, near head of Loch Fyne, November 28, 1899 (q).

Monstrilla anglica, Lubbock. Pl. xiii., fig. 13; pl. xiv., fig. 1214.

1857. Monstrilla anglica, Lubbock. Ann. and Mag. Nat. Hist. (2), vol. xx., p. 409, pl. x., fig. 7, 8 .

1900. Monstrilla (?) danoe, Scott, 18th Ann. Rept. Fishery Board for Scotland, pt. iii., p. 398, pl, xiii., fig. 15-20.

Description of the Female.-The specimen represented by the drawing measures $3.2 \mathrm{~mm}$. (nearly $\frac{1}{8}$ of an inch); it has a general resemblance in size and structure to Monstrilla longicornis, but is scarcely so robust (fig. 13, pl. xiii.).

The antennules are elongated and slender and indistinctly three-jointed; the basal joint is as usual very short; the next, which is not very clearly defined, is also small, but longer than the basal joint; the remaining portion consists of a single piece which may be made up of two or three coalescent joints (fig. 12 , pl. xiv.).

The fifth pair of thoracic feet are sub-cylindrical in outline, and nearly twice as long as broad; each foot is furnished with two elongated apical setæ, and the inner margin, which is nearly straight and shorter than the outer margin, terminates in a small rounded process, beyond which the distal portion of the foot becomes narrower as shown in the drawing (fig. 13, pl. xiv.).

The genital filaments are scarcely equal in length to the furcal setæ.

The abdomen appears to consist of three segments; the first segment is about twice the length of the secoud, while the second is about one and a half times the length of the third.

The furcal joints are each furnished with six setæ (fig. 14, pl, xiv.).

Habitat.-Firth of Forth, west of May Island, July 26, 1901; thirtyfive miles east of May Island, August 20, 1903, per s.s. "Glenogle." Females only were observed in both gatherings.

This species resembles $M$. longicornis in size, in the elongate antennules, and to some extent in the structure of the abdomen, but differs very distinctly in the armature of the fifth pair of thoracic feet, and in possessing six instead of five furcal setæ; and the integument appears to want the minutely granulated structure observed in $M$. longicornis.

The specimens recorded by me in Part III. of the Eighteenth Annual Report of the Fishery Board for Scotland from the Firth of Clyde appear to belong to Lubbock's Monstrilla anglica; these specimens were

\footnotetext{
* This specimen was of a fine green colour.
} 
apparently imperfect as regards the furcal hairs, and no doubt helped to disguise their relationship with the species named. Having now obtained specimens in fairly good coudition, I am enabled to give a few accurate figures of the female which may be of interest as supplementing Dr. Bourne's very fine drawings of the male: (See the Quarterly Journ. of Micros. Science, vol. xxx., pt. 4, uew series, Feb. 1890.)

Monstrilla dutia, T. Scott, sp. n. $\quad$ Pl. xiii., fig. 14 ; pl. xiv., fig. 16-18.

Description of the Female.-Body moderately slender; length of the specimen represented by the drawing is $3.3 \mathrm{~mm}$. (fully $\frac{1}{8}$ of an inch). The cephalothoracic segment is about one and a half times the entire length of the remaining thoracic segments and abdomen.

The abdomen is composed of three segments ; the first segment is about equal in size to the last segment of the thorax, the second is smaller than the next, while the second and third are together scarcely as long as the first segment (fig. 14, pl. xiv.).

The antennules are moderately stout and about half as long as the cephalothoracic segment, and composed of four joints ; the first and third joints are small, the second is about half as long again as the third, while the fourth is equal to the entire length of the throe joints (fig. 16, pl. xiv.)

The fifth pair of thoracic feet are moderately slender; each foot is narrow and sub-cylindrical at the proximal end, but becomes wider distally and terminates in two lobes; the outer lobe is larger than the inner and is furnished with three moderately long setre, the inner lobe is narrow and appears to be devoid of setæ as shown in the drawing (fig. 17, pl. xiv.).

The furcal jointe are each provided with four elongated hairs, one of them springs from near the base of the outer margin, two spring from the apex, while the fourth is attached on the inner aspect and near the middle of the joint, as seen in the drawing (fig. 18, pl, xiv.).

Habitat.-Firth of Forth, east of Inchkeith, August 14, 1891; and head of Lcch Fyne (Firth of Clyde), November 11, 1897, and November 28, 1899. No males have been observed.

Remarks. - The Copepod of which I have just given a description does not agree with any described species known to me. The character's by which it may be distinguished are the following three: first, the structure of the abdomen, the first segment of which is as large as the segment of the thorax next to it; second, the peculiar form of the fifth pair of thoracic feet; and, third, the number and arrangement of the furcal setæ.

Monstrilla dubia as described and figured here has a somewhat close resemblance to the female of $\boldsymbol{M}$. danoe as represented by the beautiful drawings of Professor Claparède,* and especially by figure 3, taf. xvi., which shows the female from the under side; the proportional lengths of the abdominal and of the posterior thoracic segments are almost identical, but the furcal joints are represented with only three setæ; there is also a slight difference in the length of the second joint of the antennules. Had a separate drawing of the fifth pair of thoracic feet of the female been given by that author the identification of the species would have been rendered zore certain.

\footnotetext{
* Beobachtungen uber Anatomie und Entwicklungsgeschichte wirbelloser thier an der küste von Normandie, Angestellt, p. 95, taf. xvi., fig. 1-6 (1863).
} 


\section{Genus ThaumaleusKröyer, 1849.}

Thaumaleus thomsoni, Giesb. Pl. xiv., fig. 1-4.

1892. Thaumaleus thomsoni, Giesb., Pelag. Copep. des Golfes v. Neapel, p. 584, pl. 46, fig. 7, 27, 31, 36, 40.

1902. Thaumaleus thompsoni, Scott, 20th Ann. Rept. Fishery Board for Scotland, pt. iii., p. 470, pl. xxv., fig. 5, 6 .

In Part III. of the Twentieth Annual Report of the Fishery Board for Scotland, I published a description with figures of the male of Thaumaleus thompsoni taken in Lerwick Harbour, Shetland. Recently, when examining a small collection of Monstrillas that had been captured from time to time during the past twelve or fifteen years, I found a single female of the same species that had been taken in a tow-net sample collected off Scarborough on July 9, 1893, during some investigations on behalf of the Fishery Board for Scotland; this specimen I will now briefly describe, and illustrate the description with figures showing a few of its more characteristic features.

The specimen referred to was elongated and very slender, and measured $4.8 \mathrm{~mm}$. in length (about $\frac{1}{5}$ of an inch). The cephalothoracic segment was about equal to twice the entire length of the remaining segments of the thorax and abdomen combined (fig. 1, pl. xir.).

The antennules are short and stout, and appear to consist of four joints; but the third, which is small, seems to be partly coalescent with the second (fig. 2, pl. xiv.).

The fifth pair of thoracic feet are moderately large, foliaceous, and are abruptly wider at the distal extremity, the result of a lobe-like process on the inner distal aspect; each foot carries three apical setæ, the innermost of which is considerably shorter than the other two, as shown in the drawing (fig. 3, pl. xiv.).

The abdomen consists of two segments; the first is fully half as long as the last segment of the thorax, and larger and more dilated than the second segment. The short furcal joints carry three moderately elongated setæ (tig. 4, pl. xiv.).

The structure of the fifth pair of thoracic feet, and the form of the abdomen referred to above, seem to be characteristic of this species.

Thaunaleus rigidus (I. C. Thompson). Pl. xiii., fig. 15-17; pl. xiv, fig. 19.

1888. Cymbasoma rigida, I. C. Thompson. Linn. Soc. Journ. Zool., vol. xx., p. 154, pl. xiii., fig. 1-4.

1890. Monstrilla rigida, Bourne. Quart. Journ. Micros. Science, vol. xxx., pl. xxxvii., fig. 8, 11, 12 .

1892. Thaumaleus claparèdii, Giesb., op. cit., pp. 381-385, taf. 46 , fig. 5, 15, 21, 26.

Description of the Female.--.Length of the specimen represented by the drawing (fig. 15, pl. xiii.), $2 \cdot 7 \mathrm{~mm}$. ( $\left(\frac{1}{9}\right.$ of an inch). The cephalothorax is moderately stout, rather wider near the anterior end, and nearly twice as long as the entire length of the remaining segments. The abdomen is composed of two segments; the first is about one and a half times the length of the last segment of the thorax, and the proximal half is more or less dilated; the second segment, which is smaller than the first, is probably composed of two coalescent segments, as a slight constriction, dividing the segment into two portions as shown by the drawing (fig. 15, pl. xiii., and fig. 19, pl. xiv.), is observable in all the specimens examined.

The antennules are short and stout and appear to be four-jointed, the first and third joints being very small (fig. 16, pl. xiii.). 
The fifth pair of thoracic feet are rather longer than broad, the terminal portion being distinctly small and wider than the proximal half; each foot carries three moderately long apical setæ, as shown in the drawing (fig. 17, pl. xiii.).

The furcal joints, which are of moderate length, are each furnished with three setæ (lig. 19, pl. xiv.).

Habitat.-Mauchrie Bay, Arran, Firth of Clyde, September 17, 1886. St. Andrews Bay, August 7, and off St. Monans, Firth of Forth, September 6, 1890. Dornoch Firth (Moray Firth district), July 30, 1895. Whitefarland Bay, Arran, Firth of Clyde, July 6, and between Arran and the Ayrshire coast, November 9, 1899. All the specimens obtained were females.

Remarks.-I have adopted I. C. Thompson's name for this form in preference to that of Dr. Giesbrecht, as I am convinced. after examining a number of individuals and comparing them with the descriptions and figures of Thompson and Bourne, that Thaumaleus rigidus (I. C. Thompson) and $T$. claparedii are identical. The antennules of the female in both are short and stout, and although Thompson's figure indicates a greater number of articulations than is observed in 'T' clapcurètii, this may be due perhaps to certain constrictions having been mistaken for joints; but what I rely on chiefly is the structure of the abdomen and the form and armature of the fifth pair of thoracic legs of the female, which, so far as they are represented by both Thompison's and Bourne's figures, are practically the same as the similar parts of $T$. clcuprictii represented by the drawings of Dr. Giesbrecht.

Thaumaleus zetlandicus, T. Scott, sp. n Pl. xiii., fig. 18, 19 ; pl. xiv., fig. $20-22$; pl. $x \nabla$. ., fig. 3,4 .

Description of the Female.-Body moderately stout and elongated; length of the specimen represented by the drawing (fig. 18, pl. ii.), $4.8 \mathrm{~mm}$. (nearly $\frac{1}{5}$ of an inch). The cephalothoracic segment is about one and a half times the entire length of the remaining segments of the thorax and abdomen.

The abdomen is composed of three segments; the first segment is distinctly larger than the last segment of the thorax and about twice the entire length of the next two abdominal segments; these two segments are sub-equal, but the second is slightly the longer of the two (fig. $22, \mathrm{pl}$. xiv.).

The antennules, which are short and moderately stout, are composed of four joints; the first and third joints are smaller than the others, while the end joint is about equal to the entire length of the other three (fig. 20, pl. xiv.).

The fifth pair of thoracic feet are short and broadly foliaceous and terminate in two broad rounded sub-equal lobes, the outer one of which is provided with three moderately long setæ; the iuner lobes do not appear to carry any setæ (fig. 21, pl. xiv.).

A male belonging apparently to the same species as the female described above is considerably smaller than it, and the cephalothoracic segment is only slightly longer than the combined lengths of the other thoracic segments (fig. 19, pl. xiii.). The length of this male, which is represented by the drawing just referred to, is $2.6 \mathrm{~mm}$. (or nearly $\frac{1}{10}$ of an inch). The antennules are five-jointed and longer than those of the female (fig. 3, pl. xv.) ; the abdomen appears to consist of four segments. the first two are sub-equal and are each distinctly smaller than the last segment of the thorax, while the last two are together only a little longer than the preceding segment. The number of furcal hairs is the same as in the female (fig. 2, pl. xv.).

Habitat.-Lerwick Harbour, Shetland, October 15, 1901. 
Remarks,-The more obvious characters by which this species may be distinguished are: the structure and lengths of the female antennules, the three-segmented abdomen, together with the proportional difference in the size of the first segment with the preceding segment of the thorax and the other two abdominal segments; and lastly, the peculiar form of the fifth pair of thoracic feet, as indicated by the various figures.

\section{Thaumaleus rostratus, T. Scott, sp. n. Pl. xiv., fig. 5-8.}

Description of the Female.-The length of the specimen represented by the drawing (fig. 5) is $3.9 \mathrm{~mm}$. (about $\frac{2}{13}$ of an inch); the first cephalothoracic segment is muderately stout, tapering gradually in front into a blunt pointed rostrum; while posteriorly the body becomes gradually narrower towards the distal extremity (fig. 5, pl. xiv.).

The abdomen is composed of three segments; the first segment is as large as the next two together, but the second is very small.

Each of the furcal joints is provided with three setæ of moderate lengths, arranged as shown in the drawing (fig. 8, pl. xiv.).

Antennules shurt and moderately stout, four-jointed and sparingly setiferous; the first and third joints are small, the second is about one and a half times the length of the third, while the last is equal to the entire length of the other three joints (fig. 6, pl. xiv.).

The fifth pair of thoracic feet are short and foliaceous, and each terminates in two unequal lobes; the outer lobe, which is narrower than the inner and projects somewhat beyond it, is furnished with three moderately long setæ; the inner lobe is broadly rounded and provided with a single seta (fig. 7 , pl. xiv.).

Habitat.-Lerwick Harbour, Shetland, October 15, 1901. Three or four specimens were obtained, all of which were females.

Remarks. - The form just described is readily distinguished by the produced forehead and by the form and armature of the fifth pair of thoracic feet.

\section{Fam. Choniostomatide, Hansen (1887).}

\section{Genus Stenothocheres, Hansen (1897).}

\section{Stenothocheres egregius, H. J. Hansen. Pl. xv., fig. 5-10.}

1897. Stenothocheres egregius, Hansen, The Choniostomatidæ, p. 89 , pl. i., fig. 1 a-e.

The Sphceronella-like form which I ascribe to Stenothocheres egregius was obtained in the marsupium of Metopa boreatis, G. O. Sars. The female represented by the drawing (fig. 5) measured about $68 \mathrm{~mm}$. in length (nearly $\frac{1}{37}$ of an inch); the body was almost suhærical in shape, but was rather longer than the height.

The antennules are small (fig. 7), and the end joint, which is furnished with two moderately long spine-like terminal setæ, is about one and a half times as long as the preceding one.

The autennæ are very minute and composed of two sub-equal joints, and they are each armed with a comparatively stout terminal spine (fig. 8).

The maxillipeds were damaged while being removed for the purpose of mounting, but the second pair, so far as they could be made out, appear to be moderately strong with stout terminal claws as indicated in figure 6.

The first pair of feet, though very small, are comparatively stout and two-branched, and both branches appear to be two-jointed; the inner branches are furnished with three apical spines, the middle one being 
moderately elongated, while the other two are short; the outer branches, on the other hand, are provided with one terminal spine which is moderately stout (fig. 9).

The second pair appear to be more slender than the first, and the inner branches are only one-jointed and bear a single moderately long apical spine; the outer branches, which are two-jointed, are only armed with a very short spine at the apex (fig. 10).

The abdomen is very small and provided with two furcal joints which bear a few minute setæ.

The Amphipod on which the parasite was observed occurred in a surface tow-net gathering collected in Aberdeen Bay on October 16, 1203. The parasite agrees very closely with the description and drawings of $S$. egregius, Hansen, as given in that author's Monograph of the Choniostomatidæ referred to above, and therefore, though the Amphipod on which it was found (Metopa borealis, G. O. Sars) is a different species from that mentioner by Dr. Hansen as the host $S$. egregius, I am satisfied that the parasite I have described belongs to that species.

The Amphipod on which Dr. Hansen obtained his specimens of S. egregius belonged to Metopa bruzelii (Goës.).

\section{Sphceronella paradoxa, H. J. Hansen. Pl. xv., fig. 17-19.}

1897. Sphceronella paradoxa, Hansen, The Choniostomatidæ, p. 118, pl. iii., fig. 4 a-l ; pl. iv., fig. 1 a-h.

The female of this Sphceronella represented by the drawing (figs. 16 and 17 ) is smaller than those described by Dr. Hansen, being ouly $.57 \mathrm{~mm}$., whereas the smallest of the specimens mentioned by that author was $.71 \mathrm{~mm}$. But with the exception of the difference in size the specimen recorded here agrees very well with the species to which it is referred. The specimen was found in the marsupium of Bathyporeic pelagica (Bate). The figure representing a side view of the parasite shows the posterior thread-like attachment considerably twisted upon itself and terminating in a sucker disc; the only other appendages visible are at the anterior end, and comprise a pair of antennules and a pair of powerful maxillipeds.

Six specimens of Bathyporeia were found to be infested with Spharonella, and all the parasites observed appeared to be adult females. The body of the female, represented by the drawings, is seen to be nearly globular, particularly when viewed from above.

The antennules are three-jointed, the end joint being the longest one and the penultimate joint the smallest; they are each provided with a few setæ (fig. 18).

The maxillipeds (fig. 19) appear also to be three-jointed; the first joint is very large, but the other two are smaller; the third is armed with a moderately stout terminal claw, and as the articulation between the first and second joints forms a hinge, the last two joints, together with the terminal claw, can be folded upon the first, and this allows the maxillipeds to be used as powerful grasping organs.

No males were observed.

Habitat.-In the marsupium of Bathyporeia pelagica (Spence Bate), collected off Lossiemouth, Moray Firth, December 29, 1903.

\section{Sphoeronella minuta, T. Scott, sp. n. Pl. zv., fig. 11-15.}

An adult Sphceronella was obtained in the marsupium of a specimen of Perioculodes longimanus (Spence Bate) from the Dornoch Firth, collected by the bottom tow-net on December 28, 1903. Dorsal and side views of the specimen are represented by fig, 12, 11. The length of the specimen is $48 \mathrm{~mm}$. (about $\frac{1}{52}$ of an inch). 
The antennules appear to be three-jointed; the first joint is nearly twice as long as the second, while the third is equal to rather more than the entire length of the first and second (fig. 13).

The first maxillipeds are very small, and consist of a single stout joint armed with a moderately strong terminal claw (ỉg. 14).

The second maxillipeds are rather more slender and elongated than the other pair; the basal joint is twice as long as broad; the next two are small and narrow, and appear to be hinged to the basal joint; the terminal claw, which is moderately stout, is slightly curved (fig. 15).

Dr. Hansen states that he obtained female Sphoeronellas in the marsupiums of three specimens of Perioculodes longimanus from Denmark, and that they appeared to be identical with S. paradoxa, the only appreciable difference being their smaller size. Dr. Hansen's extensive knowledge of this curious and difficult group of Crustacea precludes any doubt coucerning the accuracy of the identification of these specimens. I am therefore inclined to regard the Sphoeronella found on the Perioculodes from the Dornoch Firth as a somewhat different form from those he observed, and have described it provisionally under a distinct specific name.

This Sphceronella from the Dornoch Firth Perioculodes appears to differ not only in size and shape from S. paradoxa, but also in the size and proportional lengths of the joints of the antennules and in the size and structure of the second maxillipeds.

\section{Sphoeronella callisomae, T. Scott, sp. n. Pl. xv., fig. 20-27.}

The Sphceronella I record under this name was obtained on a specimen of Callisoma crenata (Spence Bate) collected at the mouth of the Firth of Clyde on February 7, 1899. The parasite is an adult female and measured $\cdot 86 \mathrm{~mm}$. in length ( $=\frac{1}{29}$ of an inch). The body seen from above is nearly globular, and the cephalon is seen projecting somewhat beyond the anterior aspect in the form of a moderately conspicuous tubercle (fig. 21). Seen from the side the body is broadly oblong, with both the anterior and posterior ends boldly convex. The anterior portion of the body appears to be thickly beset with minute hairs (fig. 20 and 21).

The antennules are three-jointed; the middle joint is very short, but the other two are moderately elongated (fig. 22).

The antennæ are very small and uniarticulate, and are each furnished with a single terminal seta about as long as the antennal joint (fig. 23).

The mandibles are slender, elongated, and sub-cylindrical (fig. 24).

The maxillæe are stout, and are each apparently composed of a single piece, and armed with two moderately stout terminal setæ, while a third seta springs from a minute lateral process, as shown in the drawing (fig. 25).

The first and second maxillipeds have each of them moderately stout basal joints, and they are each provided with strong terminal claws (fig. 26, 27).

The ventral filament, which is furnished with a terminal sucker-like disc, is long and slender, and twisted upon itself as shown in fig 20 .

This Sphoeronella does not agree with any described species known to me.

\section{Spharonella cluthae, T. Scott, sp. n. Pl. xv., fig. 28-30.}

A single adult female of this Sphceronella was obtained in the marsupium of a specimen of Harpinia pectinata, G. O. Sars, * found in a tow-net gathering collected in moderately deep water at the mouth of the Clyde estuary, and nearly midway between Ailsa Craig and Sanda Island; this tow-net gathering was collected on November 14, 1899.

* Some remarks on the distribution of this Harpinia will be found among the Notes on Amphipoda at page 256. 
This parasite, which appears to differ from any other Sphceronella known to me, measures $74 \mathrm{~mm}$. in length (about $\frac{1}{34}$ of an inch). Its form is almost globular, especially the dorsal view, but seen from the side the height is rather less than the width (fig. 28, 29).

The only appendages that could be satisfactorily made out were the second maxillipeds, and these are moderately elongated and slender, and are each provided with a slender terminal claw (fig. 30 ).

There does not appear to be any previous record of a Sphceronella having been found on Harpinia pectinata.

Sphoronella pygmoea, T. Scott, sp. n. Pl. xv., fig. 31-34.

The adult female of this species represented by the drawings (fig. 31 and 32), whether viewed dorsally or from the side, is seen to be of a nearly oval form, the length being equal to about one and a half times the breadth. This parasite, which is very small, measures only $49 \mathrm{~mm}$. in length (about $\frac{j}{51}$ of an inch).

The antennules and antennæ appear to be rudimentary, while the only appendages of which a satisfactory examination was made were the first and second maxillipeds represented by the drawings (fig. 33, 34).

The first maxillipeds, which are very small and uniarticulate, are armed with a moderately stout terminal claw (fig. 33).

The second maxillipeds are elongated and three-jointed; the inner distal angle of the first joint is produced so as to form a small bifid projection; the first and second joints are sub-equal in length; the third is small and narrow, and bears a somewhat feeble terminal claw (fig. 34).

Habitat.-This small Sphreronella was obtained in the marsupium of a specimen of Pseutlocuma similis, G. O. Sars. No males or post-larval females were observed.

There does not appear to be any previous record of a Sphoeronella from this species of Pseudocuma.

Sphoeronella amphilochi, H. J. Hansen. P1. xv., fig. 35, 36.

1897. Sphceronella amphilochi, H. J. H., op. cit., p. 139, pl. vii., fig. $3 \mathrm{a}$ and $\mathrm{b}$.

The Sphceronellu I record under this name was found in the marsupium of Amphilochoides odontony.x (Boeck) (=Amphilochoides pusillus, G. O. Sars).* The specimen represented by the drawing (fig. 35) is a young female, and as Dr. Hansen has only described the adult form of the species from a solitary example, a satisfactory comparison between our specimen and his description and figures could not be made. Dr. Hansen's specimen was, however, found on the same species of Amphipod, and this favours the identification of the two parasites as being the old and young females of the same species. The young female I am recording measured only $14 \mathrm{~mm}$. in length (about $\frac{1}{170}$ of an inch), but the size of the adult described by .Dr. Hansen was $\cdot 54 \mathrm{~mm}$.

A specimen which appeared to be an adult female was taken from the marsupium of the same Amphipod in which the young one now recorded was obtained, but it was somehow lost ere it could be thoroughly examined and figured.

The posterior part of the body of the young female is distinctly hispid, and the thoracic legs were furnished with long and slender terminal hairs, as shown in tig. 35 . Near the middle of the dorsal aspect a number of slender bristles were observed.

* Crustacea of Norway, vol. i. (Amphipoda), p. 222. See also the supplement to the volume, p. 690 , where the author restores Boeck's name, $A$. odontonyx, for the name used in the body of the work. 
The second maxillipeds were moderately powerful, but the other appendages were smaller and weaker.

As this young female agrees with none of the other young forms described by Dr. Hansen, I prefer for the present to regard it as the post larval stage of his Sphoeronella amphilochi.

As a list of the genera and species of the Choniostomatidæ described by Dr. H. J. Hansen in his interesting work on that curious group of parasitic Copepoda may be useful, I give it here. To this list I have added the few odd forms mentioned in the preceding notes, and one or two others recorded in previous Reports. The names of the hosts on which the parasites have been obtained are also given, and I have indicated by an asterisk (*) such of the species as up till now have been observed in Scottish waters. This will show how much room still remains for further research among these minute organisms.

The names of the parasites are arranged in alphabetical order on the left-hand side of the page, while the names of the hosts on which they have been found are placed immediately opposite.

\begin{tabular}{l|l}
\hline Names of the Parasites. & Names of the Hosts. \\
\hline
\end{tabular}

Gen. Aspidoecia.

*Aspidoecia normani, Giard and Bonnier.

Gen. Choniostoma.

Choniostoma hanseni, Giard and Bonnier.

Choniostoma mirabitis, H. J. Hansen.

Gen. Homoeoscelus.

Hom oscelus mediterranea, H. J. H.

Homoeoscelus minuta, H. J. H.

Gen. Mysidion.

Mysidion abyssorum, H. J. H. , commune, H. J. H.

Gen. Sphoeronella, H. J. H.

(a) Sphceronellas pa rasitic on Amphipoda.

Sphoeronella abyssi, H. J. H.

,

* 9

,9

9 antillensis, H. J. H.

acanthozonis, H. J. H. amphilochi, H. J. H. argissce, H, J, H.
Erythrops elegans, G. O. Sars ; E. servatc, G. O. Sars ; E. erythrophthalmus (Goës.); $E$. microphthalmus, G. O. Sars; and $E$. abyssorum, G. O. Sars.

Hippolyte gaimardii, M.-Edw. and H. polaris (Sabine).

", gaimardii, M.-Edw.

Iphinoё trispinosa (Goodsir).

Diastylis lucifera (Kröyer).

Erythrops abyssorum, G. O. Sars.

Erythrops serrata, G. O. S.; $E$. abyssorum, G. O. S.; and Parerytlırops obesa, G. O. S.

Astyra abyssi, Boeck.

A canthozone cuspidata (Lepech.).

Amphilochoides odontonyx (Boeck). (=Amphilochoides pusillus, G. O. Sar's).

Corophium bonelii, M.-Edw.

Argissa hamatipes, Norman (=A. typica, Boeck). 


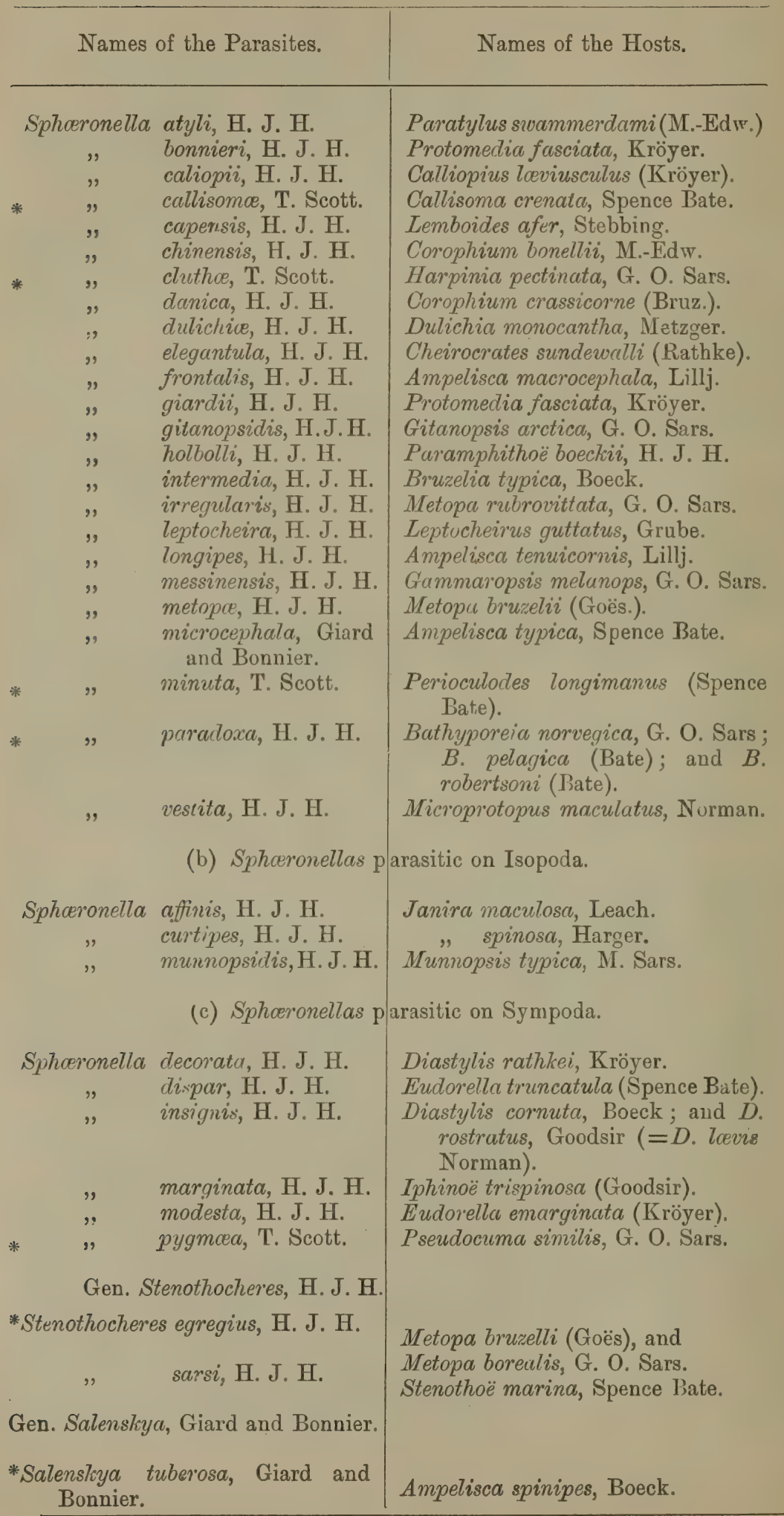




\section{AMPHIPODA.}

The following notes on some species belonging to the Amphipoda and one or two other groups of the Malocostraca obtained in planktonsamples collected during the investigations recently carried out by Dr. T. Wemyss Fulton in the North Sea and the Moray Firth-may be of interest.

Hyperia medusarum (O. F. Muller). This species, which appears to have a decidedly northern and Arctic distribution, and of which there is so far no authentic British record, was obtained in a surface planktonsample collected about 180 to 185 miles east by north of Aberdeen on October 8th, 1903. One or two full-grown females and several young specimens were noticed. In the same gatherings there were observed Clione borealis and Limacina retroversa-two northern Pteropods-as well as Tryphosa nanoides, Hoplonyx cicada, and some other and commoner forms.

Tryphana malmi, Boeck. This curious and brightly colonred little Amphipod occurred in a surface gathering collected off the Ord of Caithness, Moray Firth, on November 21st, and in a bottom gathering collected off Lossiemouth on December 29th, 1903. This is the first time I have met with Tryphana so close to the Scottish north-east coast, but the Rev. Canon A. M. Norman records its occurrence at Banff, whence specimens were sent to him many years ago by Thomas Edward.* Professor G. O. Sars in his great work on the Crustacea of Norway records this species from three different places on the west coast of Norway, and only from deep water; he states further that Boeck also obtained it in deep water in Hardangerfjord. $\dagger$ The only other localities which Norman gives in his note on the distribution of the species are the Faroe Isles and North Atlantic, lat. $18^{\circ} 8^{\prime}$, long. $30^{\circ} 5^{\prime} \mathrm{W}$. (Stebbing). Tryphana malmi may, however, be less rare thall the apparent dearth of information concerning its distribution would seem to imply. I have obtained it in at least two plankton-samples from the Shetland Islands, in addition to the two mentioned above. $\ddagger$

Anonyx nugax (Phipps). This species, rarely met with in the British seas, was captured in Aberdeen Bay on December 23rd, 1903. The species was taken for the first time in Scottish waters in February, 1889; on that occasion it was obtained near May Island, at the mouth of the Forth estuary.§ It was again met with in January, 1901, in the Cromarty Firth, when specimeus collected on the 10 th of that month by Mr. F. G. Pearcey were forwarded to the Fishery Board's Laboratory at Bay of Nigg, near Aberdeen, $\|$ and the present record of its occurrence in Aberdeen Bay is the only other occasion on which it has been observed off the east coast of Scotland. None of the Scottish specimens of Anonyx nugax have attained to anything like the size of some Arctic examples.

Hoplonyx cicada (Fabricius). This species, which, like the last, is also a northern form, has already been referred to in the note on Hyperia

* British Amphipoda of the Tribe Hyperiidæ, \&c., Ann. and Mag. Nat. Hist., (7), vol. v., p. 133 (January j900).

+ Crustacea of Norway, vol. i., Amphipoda, p. 18.

Conseil permanent Intermational pour l'exploration de la Mer; Bull. des Results, Pt. D., for August, 1903, pp. 44-47.

§ Eleventh Ann. Rept. of the Fishery Board for Scotland, Part III., p. 212, pl, v., fig. 18-20 (1893).

Nineteenth Ann. Rept. of the Fishery Board for Scotland, Pt. III., p. 258 (1901) 
medusarum; but the largest specimen observed in the collections under consideration was obtained in the same gathering with Anonyx nugax, from Aberdeen Bay. Though the species appears to be widely distributed along the west side of the British Islands, the records of its occurrence on the east coast of Scotland appear to be very few, and its presence in Aberdeen Bay is all the more interesting.

It may be stated that the gathering from Aberdeen Bay collected on I)ecember 23rd, 1903, contained a considerable number of other species of Amphipoda besides the two I have specially mentioned, and the names of the following may be given, Acidostoma obesum, Tryphosa longipes, Ampelisca spinipes, Iphimedea minuta, and one or two fine specimens of Amathilla homari. Specimens of Diastylis rostrata and Siriella armata were also observed.

Harpinia pectinata, G. U. Sars. The occurrence of the single specimen of Harpinia pectinata already mentioned in connection with Sphoeronella cluthce, whose host it was, is of sufficient interest to be specially referred to in these notes. 'The only stations that may be considered as within the British limits where this species has hitherto been observed "are all to the west of Ireland and between Ireland and Rockall."* Its capture at the mouth of the Clyde estuary may be an indication that it may be found in other places when carefully sought for. $H$ : pectinata, which seems to be confined to moderately deep water, is a form that may easily be mistaken for a more common species, the characters by which it is distinguished being not easily made out without dissection. Professor G. O. Sars speaks of it as being "by no means rare" off the south and west coasts of Norway and occurring, as a rule, in company with $H$. neglecta. The Rev. T. R. R. Stebbing has seen the Clyde specimen and contirms my identification.

Metopa borealis, G. O. Sars. The occurrence of this species in Aberdeen Bay has already been referred to under the Choniostomatidæ as one of the hosts of Sterothocheres egregius. Metopa borealis, like $M$. alderi and one or two other members of the same genus, has an unarmed telson, but with the assistance of Professor G. O. Sars' excellent monograph, it need not be confounded with any of the other species referred to. $M$. borealis is a northern form, but appears to have a fairly wide distribution; it is one of the rarer forms recorded by Dr. Robertson from the Hirth of Clyde.

Paratylus falcatus, Metzger. One or two specimens of Paratylus falcatus were obtained in a tow-net gathering collected in the Dornoch Firth on December 26th, 1903. Though this Paratylus bears a strong resemblance to $P$. uncinatus, G. O. Sars, the tooth-like posterior projections of the segments of the metasome on the dorsal aspect readily distinguish it. I have found both forms in Scottish waters, but neither of them very common.

Megaluropus agilis, Norman. This somewhat curious species, readily distinguished by the peculiar form of the eyes, was obtained in a bottom plankton-sample collected on December 29th about three miles off Lossiemouth, Moray Firth.

\section{ISOPODA.}

Idothea neglectu, G. O. Sars. Professor G. O. Sars in his great work on the Crustacea of Norway, now in course of publication, has in Volume II.

* British Ampbipoda, by Rev. A. M. Norman; Ann. and Mag. Nat. Hist., (7), vol. 
(Isopoda) described as distinct species one or two forms which previously have apparently been included with the Isopod known as Idotea tricuspidata, which was in consequence considered to be a variable species. One of the forms referred to, which Professor Sars has raised to specific rank is named by him Idothea neglecta, * and he states concerning it that it "occurs along the whole Norwegian coast from Christiania Fjord to Vadsö, and is often found in great abundance among decaying algæ in depths ranging from six to twenty fathoms." This form is probably not uncommon round the coasts of Scotland, and is, I think, included among the varieties of 'Idotea tricuspidata' described in Bate and Westwuod's Sessile-eyed Crustacea. $\uparrow$ Idothea neglecta appears to be moderately frequent in some parts of the Clyde estuary; my friend Mr. Alexander Patience of Glasgow, who first directed my attention to its occurrence in the Clyde, has obtained a considerable number of specimens, which he has been kind enough to let me examine, and there are several specimens in the collection in the Fishery Board's Laboratory, Bay of Nigg, which are also from the Clyde district. The average size of the male of this Idothea is stated by Sars to be 25 millimetres in length (=1 inch). One of the specimens in the Laboratory is, however, much larger than that, being 33 millimetres, while others in the same collection measure $28,27,25$, and 20 millimetres. The female is much smaller than the male, its average size being, according to Sars, only 16 millimetres. All the specimens in the Laboratory have been collected in different parts of upper Loch Fyne, during 1897 and 1899.

Idothea neglecta has not yet been recorded from the east coast of Scotland.

\section{SYMPODA.}

Eudorellopsis deformis (Kröyer). This curious little species was obtained in a plankton-sample collected by the s.s. "Glenogle" about fifty miles to the eastward of the May Island, Firtl of Forth, on August 20 th, 1903 ; the species has been observed in various other localities, but very sparingly and usually in moderately deep water.

Pseudocuma simitis, G. O. Sars. This species has already been referred to as the host of Sphceronella pygmoed under the Choniostomatidæ; a few specimens occurred in a plankton-sample collected in moderately deep water about three miles off Lossiemouth, in the Moray Firth, on December 29th, 1903. Pseudocuma similis resembles the more common $P$. cercaria very closely, and this may be the reason it has only recently been recognised as a British species.

A considerable number of other microcrustaceans, more or less interesting, have been noticed in various plankton-samples collected during the recent fishery investigations carried out under the direction of Dr. Fulton in the North Sea and Moray Firth. These may be described in a subsequent paper dealing more generally with that group of marine organisms.

I take this opportunity to substitute other generic names in room of two that have recently been adopted for certain forms of Copepoda, but which I now find to be pre-occupied.

(a). Genus Platypsyllus, T. Scott, Twentieth Report of the Fishery Bocu'd for Scotland (1902), Pt. III., p. 455. I fird that Platypsyllus was used in 1869 both by Dr. Ritsema and Professor Westwood for a

* Crustacea of Norway, vol. ii., p. 84., pl, xxxv, fig. 1.

† British Sessile-eyed Crustacea, vol. ii., p. 381, text figs. 
genus of Coleoptera, its use by me for a genus of Copepoda must therefore lapse, and the name I propose to substitute for it is Jeanella, the diminutive of the proper name Jean.

(b) Genus Paranthessius, T. Scott, Twenty-first Report of the Fishery Board for Scotland (1903), Pt. III., p. 120. This name has already been used by Profess or Claus for a genus of Copepoda different from that described in the Report mentioned, and it must therefore be replaced by another, and the name I propose to substitute for it is Heteranthessius.

\section{DESCRIPTION OF THE PLATES.}

\section{PLATE XIII.}

Monstrilla longicornis, I. C. Thompson.

Diam.

Fig. 1. Female, dorsal view

Hig. 2. Male, dorsal view

Fig. 3. Antennule, female

Fig. 4. Fifth pair of thoracic feet, female

Fig. 5. Abdomen and caudal furca, female

Fig. 6. Antennule, male

Fig. 7. Abdomen and caudal furca, niale, ventral aspect

Monstrilla gracilicauda, Giesbrecht.

Fig. 8. Female, dorsal view . . . . . . $\quad \times 35$.

Fig. 9. Antennule, female . . . . . . $\times 53$.

Fig. 10. Abdomen and caudal furca, female, . . . . $\times 79$.

Monstrilla grandis, Giesbrecht.

Fig. 11. Female, dorsal view . . . . . . $\quad \times 26$.

Fig. 12. Male, dorsal view $\quad . \quad \therefore \quad \therefore \quad \times 35$. $\quad . \quad$

Monstrilla anglica, Lubbock.

Fig. 13. Female, dorsal view . . . . . . . $\times$

Monstrilla dubia, T. Scott, sp. n,

Fig. 14. Female, dorsal view

Thaumaleus rigidus, I. C. Thompson.

Fig. 15. Female, dorsal view

Fig. 16. Antennule, female

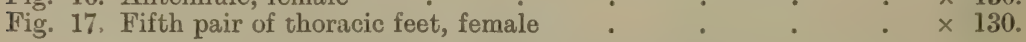

Thaumaleus zetlandicus, T. Scott, sp. $\mathbf{n}$.

Fig. 18. Female, dorsal view

Fig. 19. Male, dorsal view

\section{PLATE XIV.}

Thaumaleus thompsoni, Giesbrecht.

Fig. 1. Female, dorsal view

Fig. 2. Antennule, female

Fig. 3. Fifth pair of thoracic feet, female

Fig. 4. Abdomen and caudal furca female 
Thaumaleus rostratus, T. Scott, sp. n.

Fig. 5. Female, dorsal view

Fig. 6. Antennule, female

Fig. 7. Fifth pair of thoracic feet, fenale

Fig. 8. Abdomen and caudal furca, female

Diam.

$\times 26.5$.

$\times 79$.

79 .

79.

Monstrilla grandis, Giesbrecht.

Fig. 9. Antennule, female

Fig. 10. Fifth pair of thoracic feet, female

Fig. 11. Abdomen and caudal furca, female

Monstrilla anglica, Lubbock.

Fig. 12. Antennule, female

Fig. 13. Fifth pair of thoracic feet, female

Fig. 14. Abdomen and caudal furca, female

Monstrilla gracilicauda, Giesbrecht.

Fig. 15. Fifth pair of thoracic feet, female

Monstrilla dubia, T. Scott, sp. n.

Fig. 16. Antennule, female

Fig. 17. Fifth pair of thoracic feet, female

Fig. 18. Abdomen and caudal furca, female

Thaumaleus rigidus, I. C. Thompson.

Fig. 19. Abdomen and caudal furca, female

Thaumaleus zetlandicus, T. Scott, sp. n.

Fig. 20. Antennule, female

Fig. 21. Fifth pair of thoracic feet, female

Fig. 22. Abdomen and caudal furca, female

\section{PLATE XV.}

Monstrilla grandis, Giesbrecht.

Fig. 1. Antennule, male .

Fig. 2. Abdomen and caudal furca, female $\quad: \quad \cdot \quad \cdot \quad \cdot \quad \times 106$

Thaumaleus zetlandicus, T. Scott, sp. $\mathrm{n}$.

Fig. 3. Antennule, male .

Fig. $4 . \quad \times \quad \times 53$

Fig. 4. Abdomen and caudal furca, male . . . . $\quad$. $\quad \times 79$.

Stenothocheres egregius, Han.

Fig. 5. Side view, female

Fig. 6. Dorsal view, female

Fig. 7. Antennule, female

Fig. 8. Antenna, female .

Fig. 9. Foot of first pair

Fig. 10. Foot of second pair

Spharonella minuta, T. Scott, sp. $\mathrm{n}$.

Fig. 11. Female, side view

Fig. 12. Female, dorsal view

Fig. 13. Antennule

Fig. 14. First maxilliped :

Fig. 15. Second maxilliped 


\section{Spharonella paradoxa, Han.}

Fig. 16. Female, side view

Fig. 17. Female, dorsal view

Fig. 18. Antennule

Fig. 19. Maxilliped

Spharonella callisoma, T. Scott, sp. n.

Fig. 20. Female, side view

Fig. 21. Female, dorsal view

Fig. 22. Antennule

Fig. 23. Antenna

Fig. 24. Mandible.

Fig. 25. Maxilla

Fig. 26. First maxilliped .

Fig. 27. Second maxilliped

Spharonella clutha, T. Scott, sp. n.

Fig. 28. Female, side view

Fig. 29. Female, dorsal view

Fig. 30. Second maxilliped

Spharonella pygmaea, T. Scott, sp. n.

Fig. 31. Female, side view

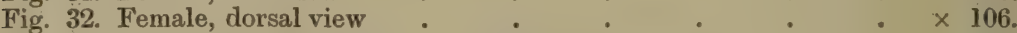

Fig. 33. First Maxilliped

Fig. 34. Second Maxilliped

Spharonella amphilochi, Has

Fig. 35. Female, side view

Fig. 36. Antennule of the same 




\section{B. KEPORT, 1904.}

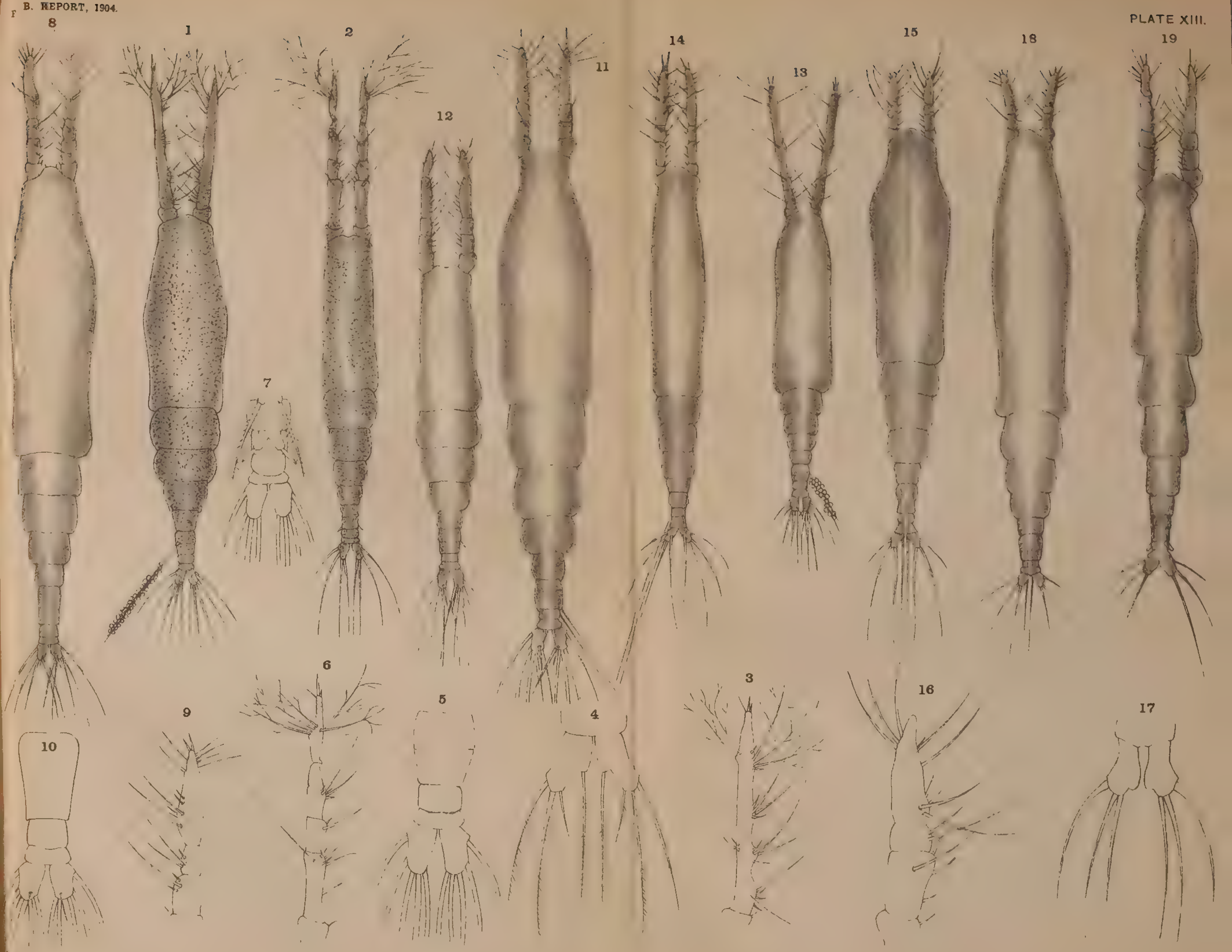











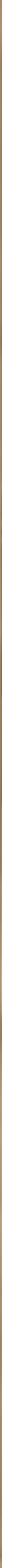







\section{3f $=3$}

$\Rightarrow+5250$

$2 \pi$

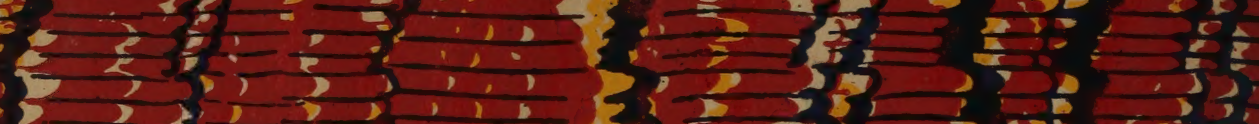

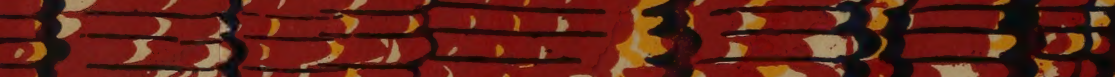

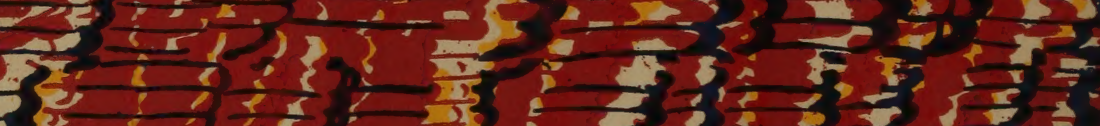

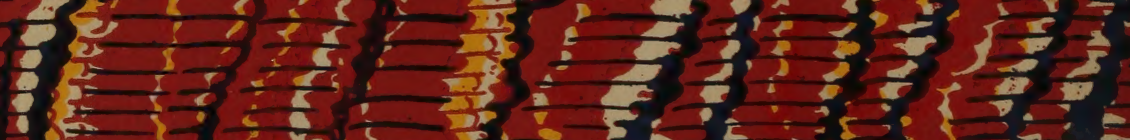

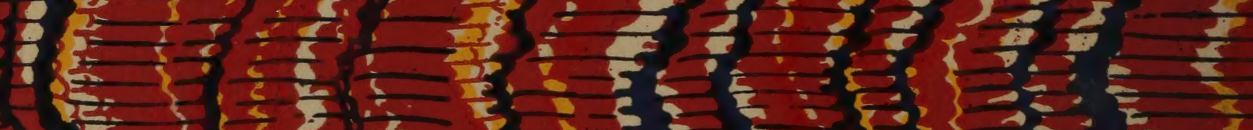

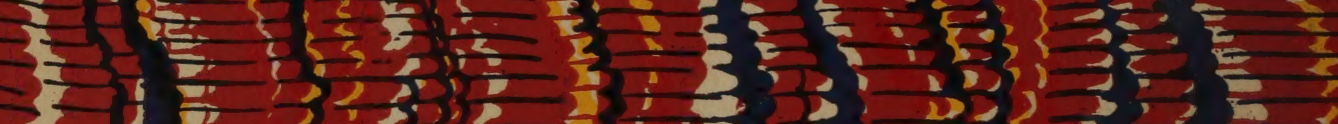

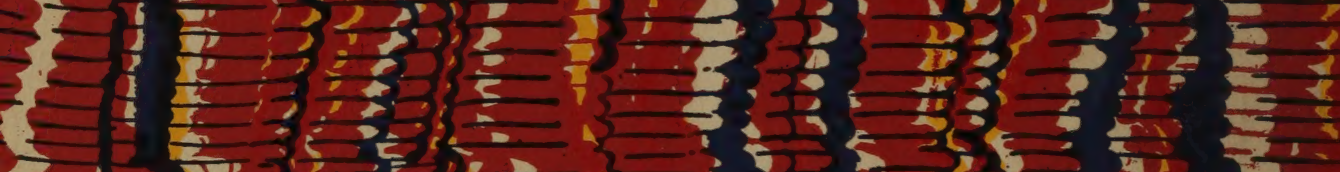
सं का

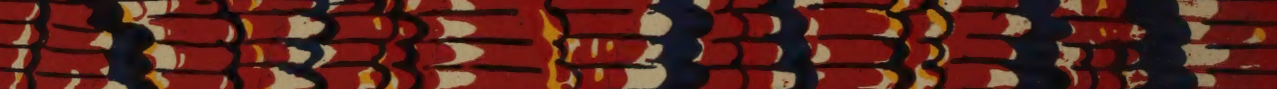

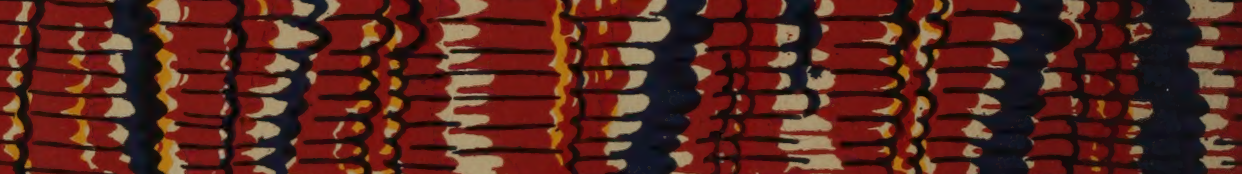

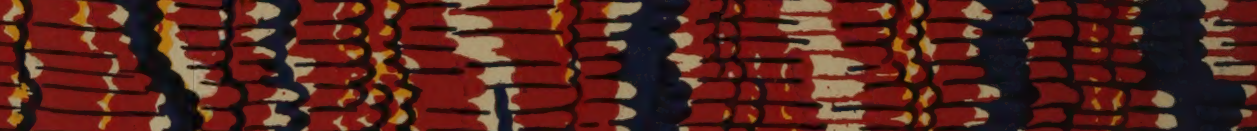

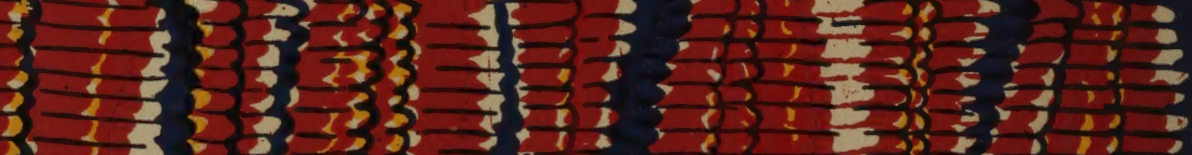

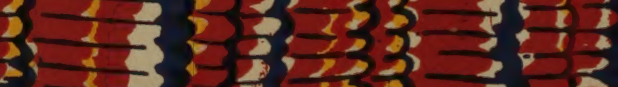

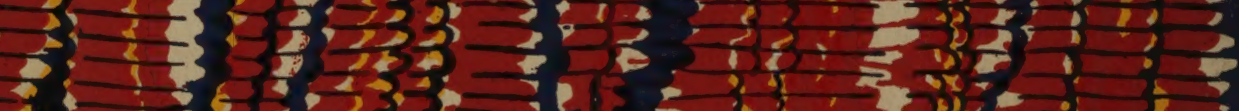

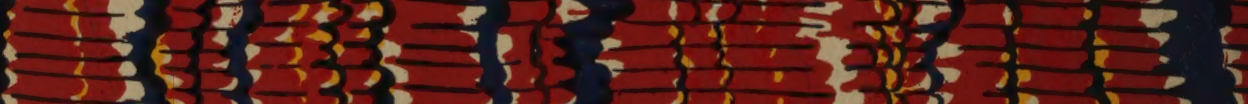

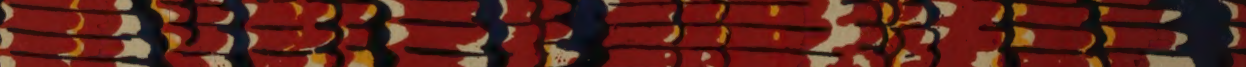

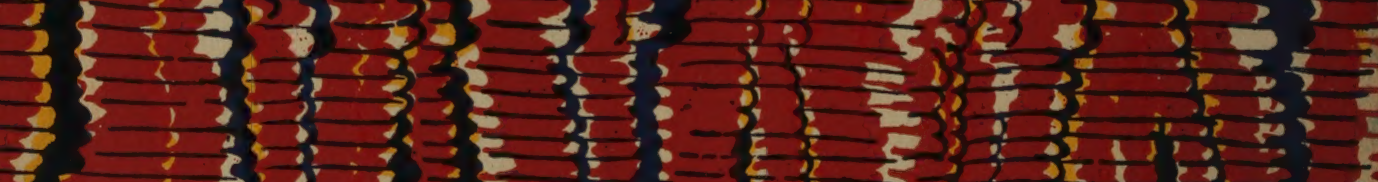

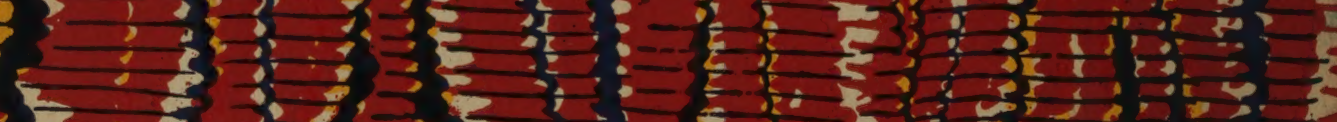

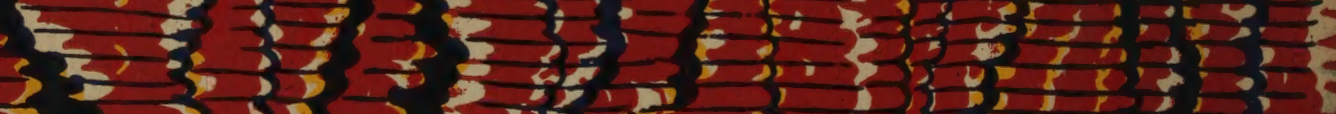

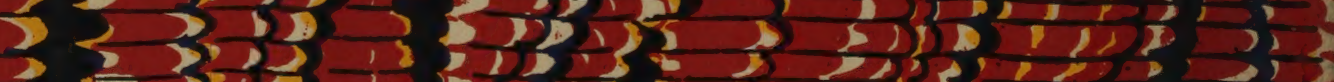

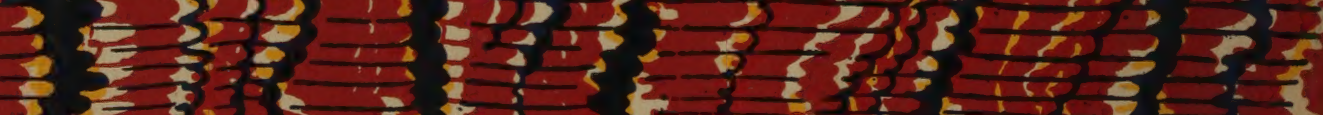

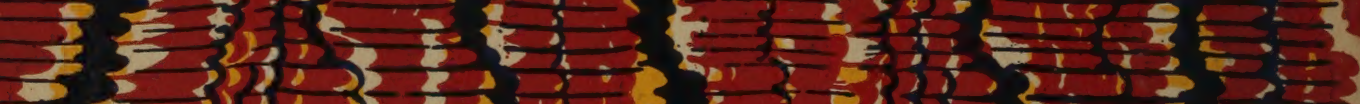

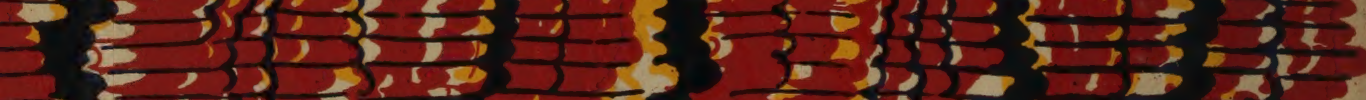

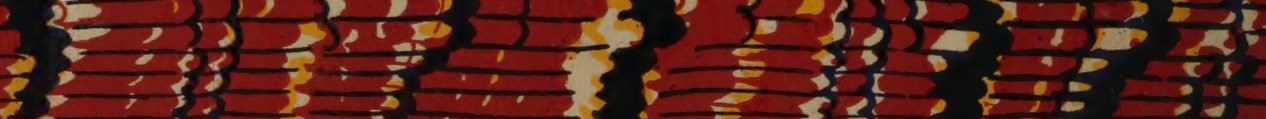

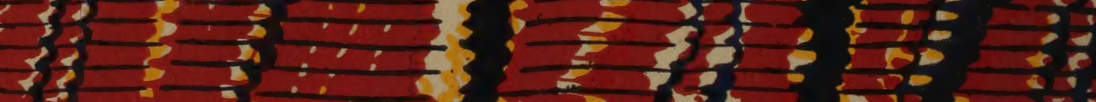

$=\left\{\begin{array}{l}2 \\ =\end{array}\right.$

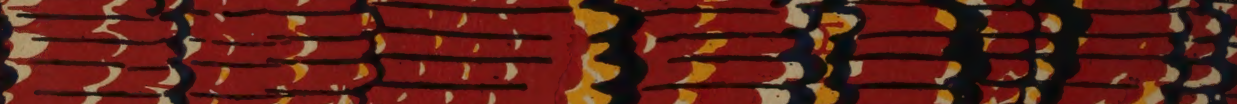

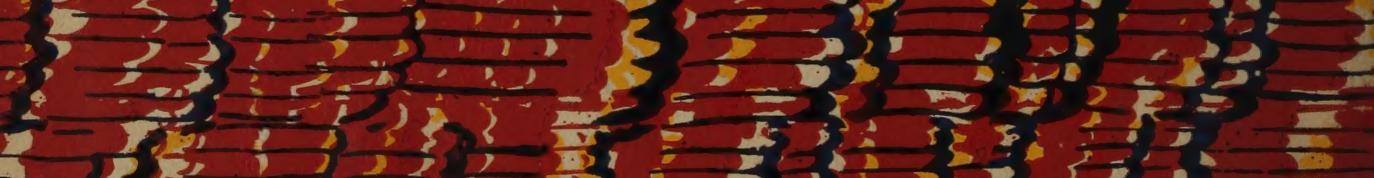

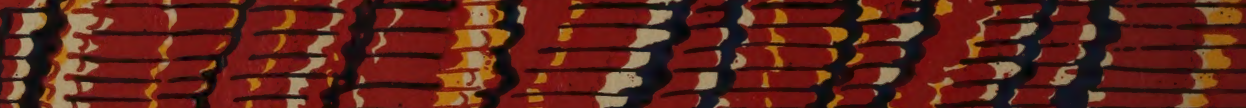

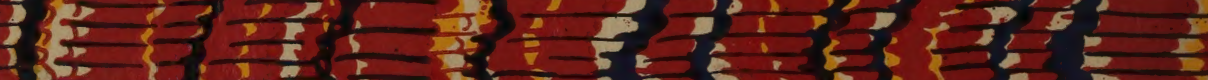

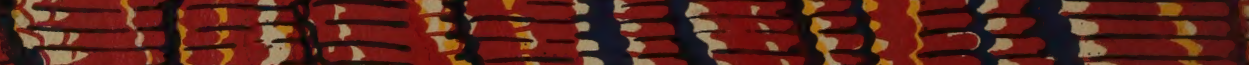

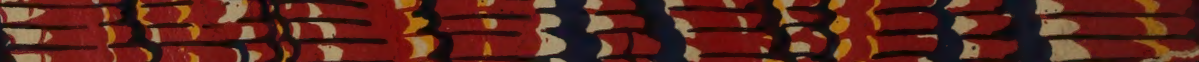




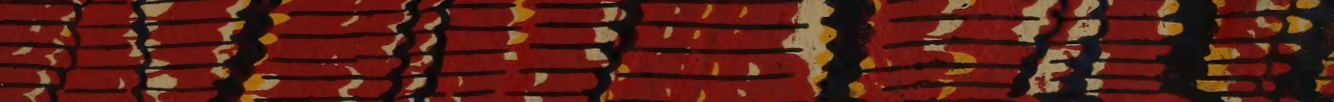

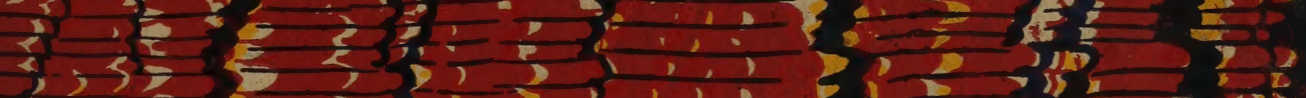

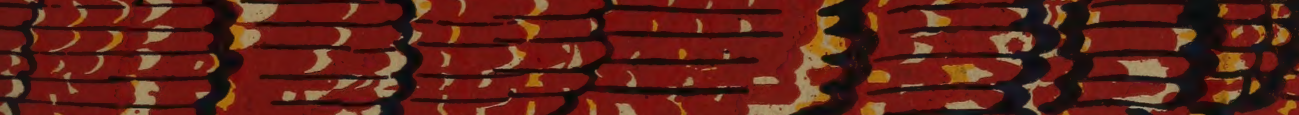

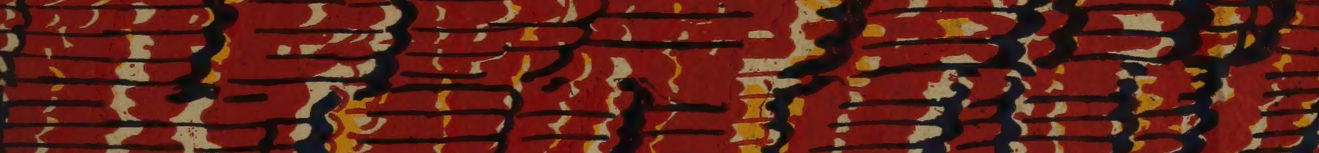

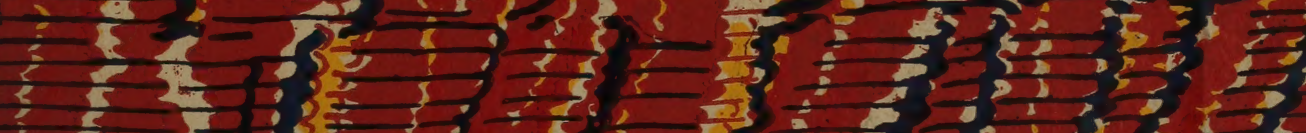

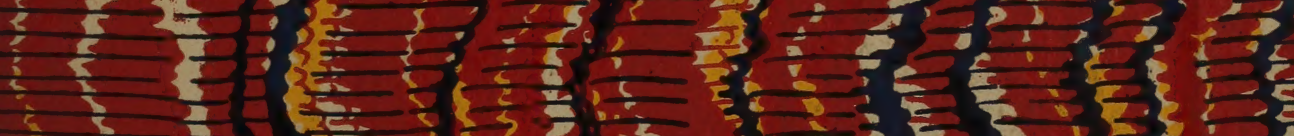

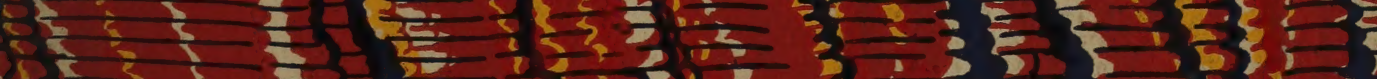

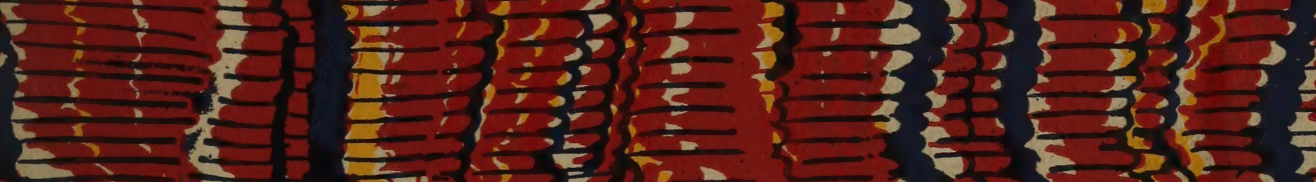

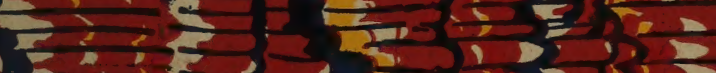

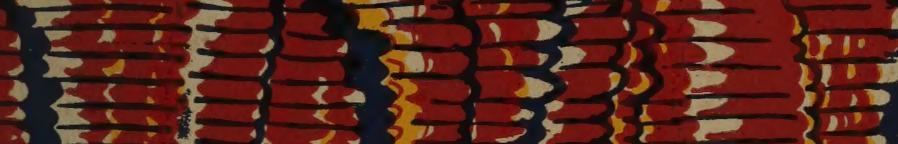

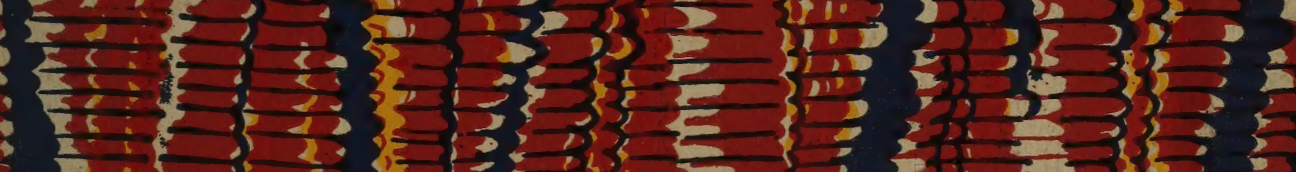

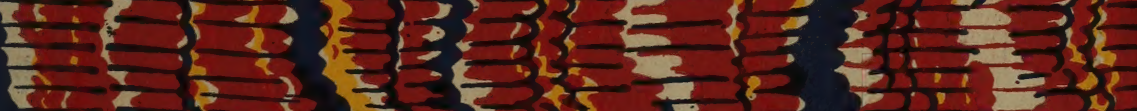

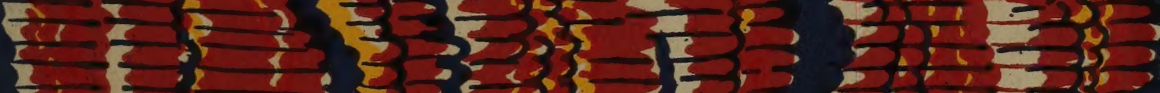

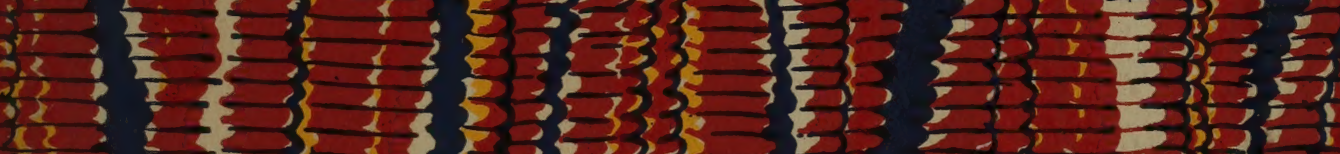

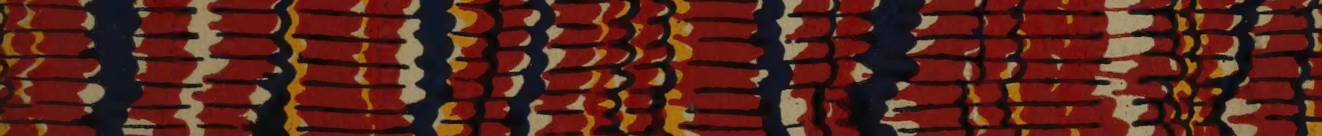

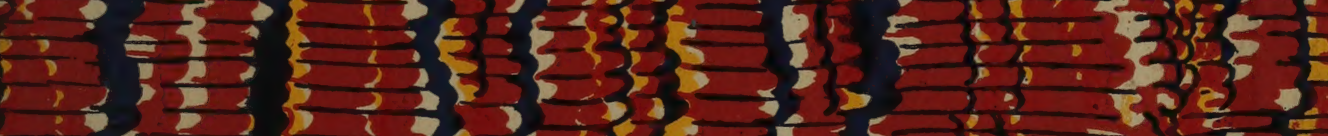

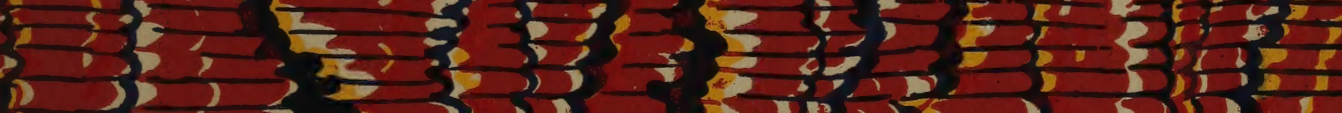

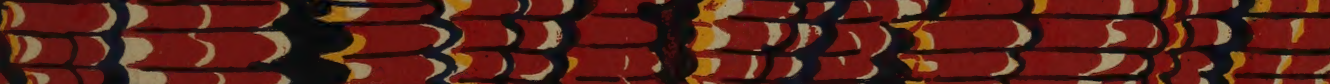

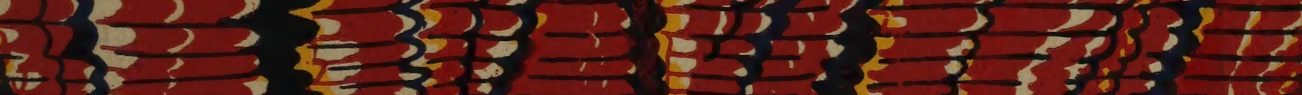

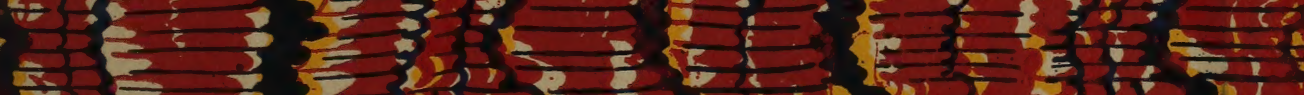

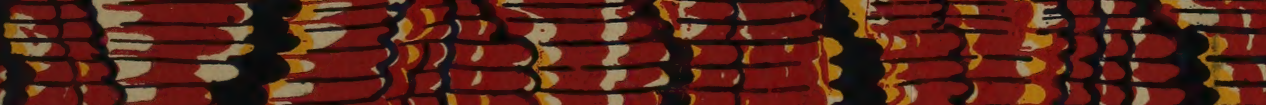

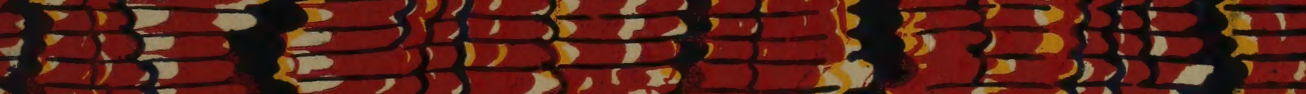

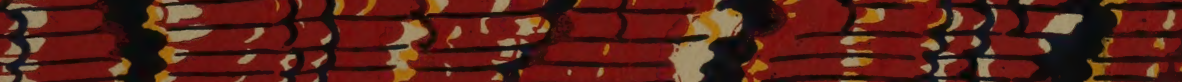

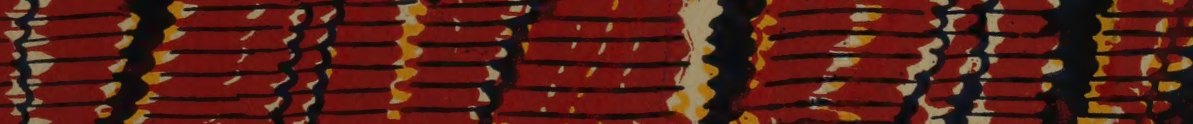

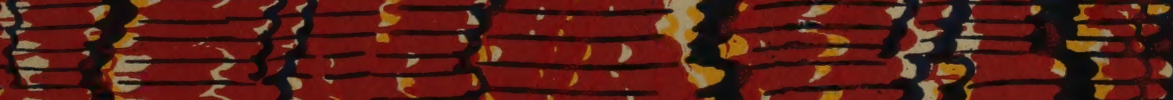
Fi

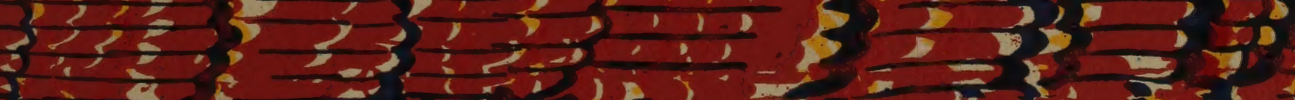

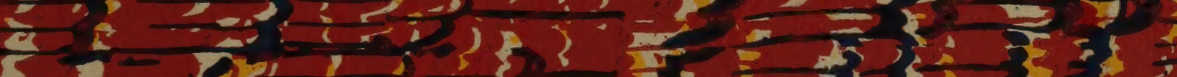

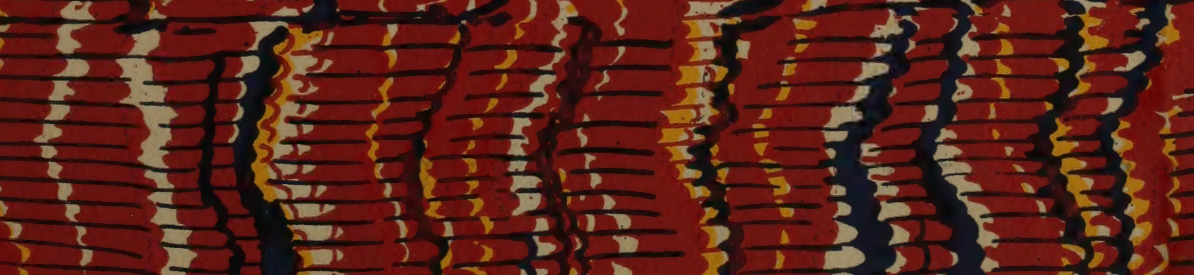


